\title{
New Insights Into Hematological, Serum Biochemical and Histopathological Toxicity of Bisphenol a on Bighead Carp (Aristichthys Nobils) Under Long-Term Exposure
}

\section{Rabia Akram}

BZU: Bahauddin Zakariya University

\section{Rehana Iqbal}

Bahauddin Zakariya University

Riaz Hussain ( $\nabla$ dr.riaz.hussain@iub.edu.pk)

Islamia University of Bahawalpur: The Islamia University of Bahawalpur Pakistan

https://orcid.org/0000-0003-3058-1371

\section{Muhammad Ali}

Quaid-i-Azam University Islamabad: Quaid-i-Azam University

\section{Research Article}

Keywords: Bisphenol A, Aristicthys nobilis, blood-biochemistry, gills, brain, heart

Posted Date: February 16th, 2021

DOI: https://doi.org/10.21203/rs.3.rs-186716/v1

License: (c) (1) This work is licensed under a Creative Commons Attribution 4.0 International License.

Read Full License 


\section{Abstract}

Bisphenol A (BPA) is one of the highest volume chemicals produced worldwide and is frequently used in dental sealants, water bottles, food and beverage packaging. Due to persistant application, BPA has become potential threat to variety of organisms including public health. In this study for the first time 80 bighead carps were randomly placed in different four groups (A-D). Fish in groups (B-D) were treated with BPA 60 days while fish in group A served as control group. Body weight, absolute and relative weight of different visceral organs of fish exposed to higher concentrations $(1500 \mu \mathrm{g} / \mathrm{L})$ of BPA decreased significantly $(p<.05)$. Results on proximate analysis showed significantly decreased in crude proteins, lipid contents and moisture contents in muscles while increased ash contents. Red blood cells count, hemoglobin concentration, lymphocytes and monocytes were significantly decreased while leukocytes counts and neutrophil counts was significantly increased in treated fish. Results on different serum biochemistry parameters like serum albumin and total proteins decreased significantly $(p<.05)$ while alanine aminotransferase (ALT), aspartate aminotransferase (AST) and alkaline phosphatase (ALP), urea creatinine, glucose, cholesterol and lactate dehydrogenase $(\mathrm{LDH})$ increased significantly $(p<.05)$ in treated fish. Histopathological ailments like pyknosis, degeneration glomeruli, increased Bowman's space, ceroid formation in kidneys while ceroid formation, hemorrhages, pyknosis, karyorrhexis, karyolysis, binucleated hepatocytes, nuclear hypertrophy and eccentric nuclei in liver were observed in treated fish. Histological observation of ndifferent sections of brain of treated fish exhibited degenerated neurons in cerebellum, lipofuscin deposition, microgliosis, necrotic neurons, inflammatory cell and severe hemorrhage. Results on light microscopic observation of different sections of heart of bighead carp revealed necrosis, inflammatory reaction, neutrophilic myocarditis and hemorrhages. In conclusion, it is suggested that BPA induces adverse effects on physical, blood-biochemical parameters and histopathological changes in multiple visceral tissues of exposed fish.

\section{Introduction}

Over the past few decades in addition to the pathogenic risk of microbes, the indiscriminate application of synthetic chemicals in agriculture, aquatic life, industries, veterinary practice, protection of environment and to improve public health has become serious threat (Arslan et al., 2017; Richardson et al., 2017; Leem et al., 2017; Hussain et al., 2019). Accidental exposure to industrial chemicals and various environmental polutants in aquatic and terrestrial ecosytems not only cuases deaths but also reduces the life expectancy of several target and non-target organisms (Glassmeyer et al., 2016; Richardson et al., 2017; Ghaffart et al., 2019; Ghaffar et al., 2020). Several studies have indicated that the organisms in aquatic ecosystem are at huge risk than the terrestrial organisms as variety of synthetic compounds from multiple sources including industries and agriculture is shifted directly and easily to water bodies (Sivashanmugam et al., 2017; Verma et al., 2017; Amaroli et al., 2018; Baralic et al., 2019). Many of the environmental contaminants such as by-products of disinfection, fluorinated substances, bisphenol A, phthalates, pesticides and synthetic estrogens are endocrine disruptive (Smarr et al., 2016; Adoamnei et al., 2018; Barakat et al., 2017; Rattan et al., 2017; Karwacka et al., 2017). Exposure to these pollutants 
causes disturbances in biodiversity, food web, loss of habitat and multiple organ dysfunctions leading to poor reproductive performance of different organisms (Hussain et al., 2018; Hussain et al., 2019; Rubin et al., 2019; Scarano et al., 2019; Xu et al., 2018; Zhou et al., 2019).

Bio-monitoring and epidemiological reports have shown that bisphenol $\mathrm{A}$ is frequently used in paints, protective coatings, mechanical parts and as a liner in plastic food and beverage containers (Prins et al., 2017; Murata et al., 2018; Willhite et al., 2019). It has been reported that the demand of BPA at international market has expanded beyond 10 million tons (Vandenberg et al., 2013, 2019). BPA has been detected in surface water, soil, sediments and different aquatic organisms (Karthikraj et al., 2017; Sun et al., 2017; Wanda et al., 2017; Pal and Reddy, 2018; Staples et al., 2018). Studies have reported that BPA quickly and easily leaches into water (Flint et al., 2012; Bavinck, 2018) and its peak levels have been detected in landfill leachates (17.2 mg/L) and $21 \mu \mathrm{g} / \mathrm{L}$ in surface waters (Flint et al., 2012; Huang et al., 2012). The concentrations of BPA (4.4 to $8000 \mathrm{ng} / \mathrm{L})$ have been detected in fish $(0.19$ to $25.2 \mathrm{mg} / \mathrm{kg})$ obtained from Taiwan (Ching-Chang et al., 2015), 0.5 to $6 \mathrm{mg} / \mathrm{kg}$ in fish from Italy (Mita et al., 2011) and in marine fish 0.83-19.25 from Hongkong (Wong et al., 2017). Among aquatic organisms, fish are considered the most susceptible species to different endocrine disruptive chemicals and are useful biomarkers to track the quality of aquatic environment (Eggen et al., 2003; Qin et al., 2013; Faheem and lone, 2017). The exact mechanism of toxicity of BPA in exposed organisms is not clear and is still under debate. However; previous studies have shown that PBA induces its toxic effects via rapid gereation of free radicals and oxidative stress leading to multiple abnormalities in different tissues of organisms (Bavinck et al 2018; Faheem and lone, 2017). Moreover, reports are available about the physiological and Bisphenol A may enter into aquatic animals via ingestion and dermal contact with polluted water induces behavior and physical alterations such as loss of locomotion and swimming patterns. Furthermore, few reports are available about the molecular changes due to bisphenol A in liver, brain, kidneys, gills reproductive tissues of fish (Kumari and Khare, 2018; Wei et al., 2018). Hematological and biochemical parameters can be used as useful bio-indicators in fish and are well known targeted organs of toxicity after exposure to xenobiotics (Singh and Srivastava, 2010; Gul et al. 2017; Reddy, 2017; Ratn et al, 2018; Sisodiya et al., 2018). Moreover, estimation of variations in biochemical parameters such as protein, enzymes and glucose are commonly used to evaluate the physiological changes in aquatic environments to explain stress conditions (Abdel-Latif and Khashaba 2017; Abdel-Tawwab and Hamed, 2018). The toxicity of BPA on growth (Abdel-Tawwab et al., 2018), reproduction (Kim et al., 2019), gene expression (Cervantes-Camacho et al., 2020), behavior (Faheem and Lone, 2018) and oxidative stress (Zhang et al., 2020 ) in fish has been well documented. But to the best of our knowledge, the toxicity of BPA on fresh water fish particularly in Bighead carp is scanty. Therefore, in present study, we attempted to evaluate the toxicity of BPA at sublethal concentrations in bighead carp (Aristhicthys nobilis).

\section{Materials And Methods}

\section{Toxicant and chemicals}


Analytical grade bisphenol A (BPA) with purity (99.0\%) was obtained from the chemical market Lahore, Pakistan. All the other chemicals (analytical grades) were purchased from Sigma Aldrich (St. louis Missouri, USA) and Merck (Germany). Different commercial kits used for serum analyses were purchased from Randox Company (Pvt.) Pakistan. Initially different stock solutions of bisphenol A were prepared by dissolving in absolute alcohol.

\section{Experimental species and management}

Bighead carp (Aristichthys nobilis) approximately of 150-175 g body weight, same age and length (7-8 $\mathrm{cm}$ ) were purchased from fish breeding center district Bahawalnage, Punjab province, Pakistan. All the fish were transported in plastic bags supplemented with enough amount of oxygen and stocked at the laboratory of the department of life sciences (Zoology), Islamia University of Bahawalpur. All the fish were placed in tap water in glass aquaria $\left(14\right.$ " $\left.L \times 10^{\prime \prime} \mathrm{W} \times 12^{\prime \prime} \mathrm{H}\right)$ for two weeks for acclimatization purposes. During this period, the fish were offerened commercial fish feed containing crude proteins ( $22 \%$ proteins) and groundnut oil cake in the form of pellets. The feed (2-3\% of body weight) was provided daily twice a time. The remaining feed and fecal materials from all the aquaria were removed on daily basis. The water chemistry measurements were determined (Table 1 ).

\section{Experimental treatments}

After 14 days of acclimatization, all the fish were randomly divided and kept in four different groups (AD). Each group contained 20 fish. The trial was operated in four glass aquaria containing $100 \mathrm{~L}$ water. The fish of aquarium A was maintained as control while fish present in the other three aquaria was exposed to different concentrations of analytical grade bisphenol A (BPA) with purity (99.0\%) dissolved in absolute alcohol. The fish in groups B, C and D were exposed to $500 \mu \mathrm{g} / \mathrm{L}, 1000 \mu \mathrm{g} / \mathrm{L}$ and $1500 \mu \mathrm{g} / \mathrm{L}$ Bisphenol A for a period of 60 days on the basis of earlier trial (Fukuhori et al. 2005; Huang et al. 2018). During all the experimental duration and toxicity testing, fish kept in different aquaria were fed ad libitum. The rejected feed was strained and removed on daily basis. The fecal material from each aquarium was also removed to prevent water contamination.

\section{Body mass, organ weight and histopathology}

For estimation of body mass, organ weight and histopathological changes, five fish from each group were randomly weighed, killed and dissected at days 15, 30,45 and 60 of the trial. Different tissues such as liver, kidneys, gills and brain were removed, weighed and preserved in $10 \%$ formaldehyde solution. The absolute and relative weight (\% of body weight) of different organs including brain, gills, liver, and kidneys was determined at days $15,30,45$ and 60 of the trial. For histopathological changes, visceral processed using Hematoxylin and Eosin staining procedures (Hussain et al., 2019).

\section{Hematological studies}

About $2.5 \mathrm{ml}$ blood was collected from the caudal vein of each fish with sterile 26 gauge hypodermic needle. The collected blood was immediately placed in anticoagulant coated glass test tubes. Different 
hematological parameters including red blood cells counts and total and differential white blood cell counts (Islam et al., 2019) while hematocrit \%, hemoglobin quantity and total proteins were measured according to earlier protocols (Hussain et al., 2019; Ghaffar et al. 2020) at days 15, 30, 45 and 60 of the experiment.

\section{Serum biochemical studies}

For different serological parameters, serum was separated from the blood of each fish placing on ice at different experimental intervals at days 15,30, 45 and 60 of the experiment. Various serum biochemical parameters including ALT, AST, ALP, LDH, urea, creatinine, gulucose, cholesterol and triglycerides were measured using commercially available kits (Randox company Pvt.) using a chemistry analyzer (Randox company Pvt.).

\section{Statistical analysis}

Data collected during the tral were presented as mean \pm S.E. All the collected data in each group was normally distributed and statistical analysis was carried out by one-way analysis of variance (ANOVA) using IBM SPSS statistics (version 20). The difference in mean values (mean \pm S.E) of body weight, organ weight, hematological parameters and serum biochemistry of control and treated groups was conducted by using post hoc Tukey's test at $p<0.05$.

\section{Results}

\section{Physical parameters}

The results revealed that the body weight of fish exposed to higher concentrations ( $1500 \mu \mathrm{g} / \mathrm{L})$ of BPA decreased significantly $(p<.05)$ compared to control group at day 60 of the experiment (Table 1$)$. The absolute weight of visceral organs of fish such as liver, kidnyes and gills increased significantly at higher concentrations $(1500 \mu \mathrm{g} / \mathrm{L})$ of BPA (Table 1). The relative weight of liver, kidnyes and gills increased significantly $(p<.05)$ at higher concentrations $(1500 \mu \mathrm{g} / \mathrm{L})$ of BPA while non-significat difference was recorded in relative weight of brain as compared to untreated control fish (Table 2).

\section{Proximate Analysis}

Proximate analysis of A.nobilis revealed that crude protein and lipid contents significantly decreased in muscles of fish exposed to higher concentrations $(1000 \mu \mathrm{g} / \mathrm{L}$ and $1500 \mu \mathrm{g} / \mathrm{L})$ at days 45 and 60 of the study. Results showed that the moisture contents also decreased significantly in muscles of fish exposed to higher concentrations $(1000 \mu \mathrm{g} / \mathrm{L}$ and $1500 \mu \mathrm{g} / \mathrm{L})$ at day 60 of experiment. Ash contents increased significantly in fish meat exposed to higher concentrations $(1000 \mu \mathrm{g} / \mathrm{L} \& 1500 \mu \mathrm{g} / \mathrm{L})$ at day 45 and 60 of the experiment (Table 6).

\section{Hematological and serum analysis}


Results of different hematological parameters of blood cells of fish exposed to various levels of bisphenol A are presented in table 2. The fish exposed to $1000 \mu \mathrm{g} / \mathrm{L}$ and $1500 \mu \mathrm{g} / \mathrm{L}$ bisphenol A showed significantly decreased in red blood cells count at days 45 and 60 of trial. The hemoglobin concentration was significantly decreased in fish exposed to higher concentrations $(1000 \mu \mathrm{g} / \mathrm{L}$ and $1500 \mu \mathrm{g} / \mathrm{L})$ of bisphenol $A$ at days 45 and 60 of the study as compared to control fish. The fish exposed to $1000 \mu \mathrm{g} / \mathrm{L}$ and $1500 \mu \mathrm{g} / \mathrm{L}$ of bisphenol A showed that differential leukocytes counts were significantly higher (neutrophilic leukocytosis) at days 30,45 , and 60 of experiment (Table 3 ). Results showed that the lymphocytes and monocytes were significantly decreased in fish exposed to $1000 \mu \mathrm{g} / \mathrm{L}$ and $1500 \mu \mathrm{g} / \mathrm{L}$ bisphenol $A$ at days 45 and 60 of the experiment in comparison to untreated control fish. The pack cell volume of blood was also significantly decreased in fish exposed to higher concentrations $(1000 \mu \mathrm{g} / \mathrm{L}$ and $1500 \mu \mathrm{g} / \mathrm{L}$ ) of bisphenol $A$ at day 45 and 60 of the experiment.

The results on different serum biochemical parameters in fish exposed to various levels of bisphenol A are presented in table 4 . Serum albumin quantity and serum total protein significantly decreased in fish exposed to $1000 \mu \mathrm{g} / \mathrm{L}$ and $1500 \mu \mathrm{g} / \mathrm{L}$ of bisphenol $A$ at days 45 and 60 of the trial in comparison to unexposed fish. The quantity of serum alanine aminotransferase (ALT), serum aspartate aminotransferase (AST) and serum alkaline phosphatase (ALP) increased significantly in liver tissues of fish exposed to higher concentrations $(1000 \mu \mathrm{g} / \mathrm{L}$ and $1500 \mu \mathrm{g} / \mathrm{L})$ of bisphenol $A$ at days 45 and 60 of trial (Table 3). The serum triglycerides were significantly increased in fish exposed to $1000 \mu \mathrm{g} / \mathrm{L}$ and 1500 $\mu \mathrm{g} / \mathrm{L}$ at days 45 and 60 of trial. The quantity of urea and creatinine significantly increased in kidneys of fish exposed to $1000 \mu \mathrm{g} / \mathrm{L}$ and $1500 \mu \mathrm{g} / \mathrm{L}$ bisphenol A at days 45 and 60 of trial as compared to control fish. The quantity of glucose significantly increased in fish exposed to $1000 \mu \mathrm{g} / \mathrm{L}$ and $1500 \mu \mathrm{g} / \mathrm{L}$ at days 45 and 60 of the trial. The cholesterol and lactate dehydrogenase significantly increased at days 45 and 60 of the trial in fish exposed to $1000 \mu \mathrm{g} / \mathrm{L}$ and $1500 \mu \mathrm{g} / \mathrm{L}$ bisphenol A compared to control fish.

\section{Histopathology}

Results on intensity/severity of different histopathological changes if various tissues of fish exposed to various levels of bisphenol A are presented in the table 5. Various sections of gills of fish in groups C-D showed severe histopathological abnormalities such as lamellar disorganization, necrosis of lamellar pillar, lamellar atrophy, disruption of primary lamellae, curling of secondary lamellae, fusion of lamellae, severe congestion and degenration in cartilaginous cores and telangiectasia. Curling and uplifting arrangements in epithelial cells of secondary lamellae were frequently observed in these groups after day 45 and 60 of the experiment (Fig. 1). Mild to moderate histopathological abnormalities like pyknosis, degeneration glomeruli, congestion, increased Bowman's space, atrophic cells, edema, degeneration of tubular epithelium, aggregation of melanomacrophages and atrophy of the lumen of renal tubules were observed in kidneys of treated groups (Fig. 2). Moderate histopathological changes, such as deterioration of glomerulus, increased bowmens space and necrosis of tubular cells were evident in the kidneys of fish in group B at days 45 and 60 of the experiment. Moderate to sever histopathological abnormalities in liver sections including congestion, ceroid formation, hemorrhages, pyknosis, karyorrhexis, karyolysis, binucleated hepatocytes, nuclear hypertrophy and eccentric nuclei, vacuolar degeneration were observed 
in different at days 45 and 60 of the experiment (Fig. 3). Sever histopathological abnormality of liver in fish (A.nobilis) exposed to $1000 \mu \mathrm{g} / \mathrm{L}$ and $1500 \mu \mathrm{g} / \mathrm{L}$ concentrations exhibited degeneration and vacuolar degeneration, karyorrhexis, karyolysis at days 45 and 60 of the experimental study. Microscopic observation of different section of brain of untreated brain tissues showed no pathological changes while different microscopic changes including intracellular edema, congestion, necrosis of neurons and cytoplasmic vacuolization were observed at days 45 and 60 of the experiment. Histopathological analysis of different sections of brain of bighead carp exposed to higher concentrations of BPA exhibited degenerated neurons in cerebellum, lipofuscin deposition, microgliosis, necrotic neurons, inflammatory cell and severe hemorrhage at days 45 and 60 of the trial (Fig. 4). Mild to moderate similar histopathological changes in various sections of brain of fish exposed to $1000 \mu \mathrm{g} / \mathrm{L}$ BPA were observed at days 45 and 60 of the experiment. Histopathological observation of different sections of heart of bighead carp exposed to higher levels of BPA $(1000 \mu \mathrm{g} / \mathrm{L}$ and $1500 \mu \mathrm{g} / \mathrm{L})$ showed neutrophilic infiltration, necrosis, inflammatory reaction, edema, neutrophilic myocarditis, hemorrhages and deposition of fibrin were observed (Fig. 5). Vaious histopathological ailments in intestine such as extensive vacuolation of enterocytes, inflammatory response, congestion, necrosis and sporadic hemorrhages were observed in bighead carp exposed to BPA $(1000 \mu \mathrm{g} / \mathrm{L}$ and $1500 \mu \mathrm{g} / \mathrm{L})$ at days 45 and 60 of the trial.

\section{Discussion}

Bisphenol A is a commercially used chemical, an additive in the production of polycarbonate plastics as a developing agent in the manufacturing of thermal paper and epoxy resins. Bisphenol $A$ is also present in dental sealants, water bottles, and baby bottles, paper coatings, adhesives, flame retardants, food, and beverage packaging (Staples et al., 1998). Bisphenol A is one of the highest volume chemicals produced worldwide and its demand is increasing due to the ever-increasing demand and production of plastic products. Since aquatic environments are the ultimate sink of all anthropogenic chemicals, aquatic animals including fish are often exposed to these chemical compounds (Routledge et al., 1998, Metzler and Erica, 2001). In the present study, Absolute organ weight increased and relative organ weight of all of the visceral organs (Gills, Liver, and kidney (Table: 1,2) except the brain decreased in fish. Many reports on the relative organ weight of different vertebrates exposed to different toxicants are available in previous studies but scanty of information available about bisphenol A effect on absolute and relative organ weight of freshwater fish. In previous research work, similar results showed like decrease in the relative weight of visceral organs (liver, kidneys) was observed in fish (Gaffar et al., 2019; Hussain et al., 2019) rats (Rattus norvegicus) (Rubin et al.,2019; Cervantes-Camacho et al., 2020) exposed to different toxicants. Hematological parameters of blood are considering the greatest indicator of physiological stress in the various aquatic and terrestrial organisms (Ghaffar et al., 2017a). In the present study, decreased hemoglobin concentration, lymphocytes, monocytes, and pack cell volume in fish exposed to bisphenol A has been reported. Parameter values are lowered due to the rapid oxidation of hemoglobin, hemolysis, and destruction of erythrocytes (Ghaffar et al. 2016; Gul et al. 2017). RBCs reduction, increased WBCs and neutrophils also observed in present work at higher concentrations of bisphenol A. An increase in neutrophils count could be due to immunological reactions expressive to injury in tissues 
of exposed big head carp. While in previous reports, similar results like RBCs reduction decreased in $\mathrm{Hb}$, MCHC, and increase in WBCs and neutrophils were studied in common carp (Ghaffar et al., 2018), African catfish (Nashwa, 2014; Sisodiya et al., 2018) Labeo rohita (Krishnapriya et al., 2017) and Clarias gariepinus (Pathania et al., 2019) exposed to sublethal concentrations of bisphenol A. Hematological abnormalities may be due to erythrocyte destruction in blood-forming cells, increase the production of free radicles, and poor supply of oxygen through gills. Moreover, many reports of hematological parameters are also available on other vertebrates like the Albino mouse (Moselhy, 2015), Rats (Karnam et al., 2015) Yellowfin seabream (Yaghoobi., 2017), and adult cockerels (Hussain et al., 2019) exposed to toxicants. In the present research work, tissue damage observed in bighead carp caused by a higher concentration of BPA. Damage may occur due to stress conditions which induced the inflammatory response of fish tissues led to overproduction of white blood cells. Serum biochemistry analysis gives a clear indicator of pollutant exposure which is a mirror image of environmental contamination, which is useful for tissue pathophysiological status identification (Sayed and Hamed 2017; Abdel-Tawwab and Hamed, 2018). Furthermore, it has been reported that bisphenol A induces adverse effects on serum biochemical index in adult fish, leading to a defect in growth performance and fish health (Wang et al. 2016). In the present study, serum biochemical parameters like ALT, AST, and ALP increased significantly in treated fish in association to stress induced by bisphenol A. Serum biochemical parameters like serum albumin quantity and serum total protein decreased in the present investigation. However, increased glucose, cholesterol, and lactate dehydrogenase level were observed due to stress conditions in treated fish. Serum creatinine and uric acid are essential factors for muscle and purine metabolism for renal safety and kidney function (Hamed and Tawwab, 2017). Urea and creatinine levels were also increased in the liver and kidney which indicated that disturbance in filtration mechanisms and damages of kidneys and liver tissues of fish exposed to bisphenol A in the current experiment. Many previous reports are also available in other species exposed to bisphenol A. Previously, abnormal liver, kidney enzymes, an increase in hepatic enzymes as ALT, ALP, AST, abnormal urea ad creatinine, fatty liver disease, edema, vacuolation of hepatocytes, abnormal structure of cells, degeneration of structural protein due to increase in hepatic enzymes were observed in O. niloticus (Abdul-Tawwab and Hamed, 2018), Zebrafish (Renaud et al., 2017; Ngo et al., 2017 ), C. catla (Faheem et al., 2019), C. gariepinus (Makinwa \& Uadia, 2017) H. fossilis (Pal \& Reddy, 2018) due to exposure of bisphenol A. Moreover, in literature, many reports of serum biochemistry are present on other species like rats (Pal et al., 2017; Geetharathan \& Josthna, 2016).

In the current study, histopathological responses of the fish indicate the degree of damage caused by BPA to the liver of fiah (A.nobilis). In this present research work, histopathological lesions in liver tissues of fish were congestion, decreased cytoplasmic space, vacuolar degeneration, increased sinusoidal space, karyolysis of hepatocytes, and necrosis exposed to the higher concentration of BPA. Similar results are available in previous other species of aquatic organisms like ruptured central vein, lipids like vacuolization, macrophage, and lymphocytes infiltration, ruptured and degenerated hepatocytes in Ctenopharyngodon Idella (Faheem et al., 2017), seabream (Carnevali et al., 2017) exposed to sublethal concentration of BPA. The current study suggests that bisphenol-A is capable of causing damage to vital organs (brain, gills, lungs, and liver) of fish at biologically appropriate concentrations, contributing to 
altered rates of enzymes that could potentially affect fish health and reproduction. If these fish with high BPA load are routinely eaten by humans may also cause similar health problems. In the current study, kidneys of bisphenol A treated fish also showed microscopic lesions as edema, ceroid formation, glomerular degeneration, Bowman's space, congestion atrophy of tubules, and atrophy of lumen of renal tubules. However, similar results as necrosis, vacuolation, aggregation of melanomacrophages, degeneration, blood congestion, cellular rupture, nuclear hypertrophy degeneration, pyknotic nucleus, and reduction of lumen were observed in other species of fish like Heteropneustes fossilis ( $\mathrm{Pal}$ \& Reddy, 2018), tilapia (Vasu et al., 2019), Catla Catla (Faheem et al., 2017) exposed to BPA has been reported in previous studies. Like previous studies, bisphenol $A$ is responsible for kidney damage in bighead carp in current research because kidneys are primary organs to be infected by any type of pollutant (chemical, insecticide, pesticide, etc) in water bodies (Hussain et al., 2017). The degree of the damage caused and the degenerative changes that have occurred in the brain of the fish due to BPA toxicity have been progressive over the exposure, indicate that the histopathological responses depend not only on the concentration of chemicals but also on the duration of the fish exposure time to this toxicant. Several authors have recorded various histopathological changes in fish brains after exposure to different chemical substances (Ayoola \& Ajani, 2008; Lakshmaiah, 2017; Ding et al., 2018; Murali et al., 2018; Gobi et al., 2018). Scanty of the latest information available on histopathological differences in brain tissues of fish exposed to bisphenol-A. However, few reports are present in our assessed data on histopathological changes of the brain of fish like C. gariepinus (Ayoola et al., 2008), L. rohita (Das et al., 2000), O. punctatus (Pugazhvendan et al., 2009), C. carassius (Mattsson et al., 2017), C.catla (Bose et al., 2013), O. niloticus (Ayoola et al., 2008; Ding et al., 2018), O. mossambicus (Gobi et al., 2018; Murali et al.,2018), C. carpio (Lakshmaiah, 2017) exposed to toxicants.

Literature exhibited that histopathological lesion formation in the gills of fish is a suitable tool to screen the effect of different contaminants in the freshwater ecosystem. It is because the gills are facing direct contact with water pollutants and gills are the 1st organ in which contaminants enter. Gills are those important organs that act as a medium for gaseous exchange, boundary between water and fish, ionic compounds balancer, and are responsible for osmoregulation mechanism (Gaffar et al., 2018). In the present study, histopathological lesions in the gills of fish include lamellar fusion atrophied lamellae, uplifting of lamellae, congestion, and disorganization of primary, secondary lamellae. Likewise, results as Necrosis, lamellar deformation, loss of epithelium, vacuolations, hyperplasia, tubular alteration, neoplasia, hemocyte infiltration, hypertrophy, pyknosis, and histological aberrations were observed in other organisms like Van fish (Oguz et al., 2018) and C. fluminea, (Benjamin et al., 2019) exposed to different concentration of BPA. In current research work edema, neutrophilic myocarditis, hemorrhages and deposition of fibrin were observed in heart of big head carp exposed to different concentrations of bisphenol A. In one of the previous reports, calcific aortic valve disease (CAVD), including extra-cellular matrix (ECM) alteration were confirmed by histopathology for high-level of BPA exposure, and structural defects (abnormal curvature) of the atrio-ventricular valves corresponded with impaired cardiovascular function (reduced ventricular beat rate and blood flow) were observed in zebra fish (Brown et al 2019) exposed to bisphenol A. Few reports are available on histological changes of heart in fish exposed to 
bisphenol A. However, many reports of heart histology are available on rats. Potential Toxic Effect of Bisphenol A on rats (Bahey et al., 2019, Amin, 2019, Eweda et al 2020, Rasdi et al., 2020) as myocardium in the form of disarrangement of myofibers, hypertrophy of myocytes, myocardial fibrosis, and dilatation of intramyocardial arterioles were observed in previous rsearch work. In the present study histopathological changes in intestine are extensive vacuolation of enterocytes, inflammatory response, congestion, necrosis and sporadic hemorrhages in fish exposed to different concentrations of bisphenol A. like heart and brain scanty of information about BPA effect on intestine of fish is available in my assessed reports. Previously, histological Intestinal alterations in fish Dicentrarchus labrix (peda et al., 2016) was reportd. Similarly, histopathological alteration in intestine of fish Lates niloticus (Ibrahim et al 2014), Sparus aurata (Rathee and Radha, 2015), H.fossilis (Pradip et al., 2019) were exposed to toxicants have been reported. The fish under toxicant stress started the utilization of immediate sources of energy like protein, lipid, and carbohydrate, resultantly depleting the levels of these nutritive sources in the muscles as these all are interrelated in metabolism during the citric acid cycle ( Sulekha and Marcy, 2011; Muralidharan, 2014. In the present study, protein contents depletion in the fish muscle might be because of the diversion of energy due to the toxic stress of bisphenol A (Sweilum, 2006; Sobha et al., 2007; Sulekha and Marcy, 2011; Karmai et al., 2016). The decrease in protein in the meat of fish could be due to a reduction in salt and water-soluble (Chomnawang et al., 2007) or because of autolytic degradation combine with endogenous enzymes and bacteria (Hultmann and Rsted, 2004). The decrease in protein content was probably due to the leaching of soluble components especially water proteins (Osibona and Ezekiel, 2014; Ihanacho et al., 2017). Scanty of work available on body composition on freshwater fish exposed to BPA In the present study lipid contents of fish decreased at a higher concentration of bisphenol A. Previously, similar reports available on C. gariepinus (Mahboob et al., 2018), Tilapia (Sana et al., 2017) exposed to toxicants. Presently moisture contents were also decreased like protein and lipid contents in fish exposed to bisphenol-A. However, increased moisture content was observed in C.catla, L. rohita, and C. mrigala (Ghazala et al., 2018). In the present study, Ash content increased after exposure of fish to high concentrations of bisphenol A. Similar results available previously, (Rao et al., 2010; Hussain et al., 2019). Limited information is available in the literature about an effect of industrial effluents on the proximate composition and amino acid profile of freshwater fishes and their use as a biomarker of toxicant contamination (Hussain et al., 2019). The findings of this research work have indicated that industrial contaminant (bisphenol A) probably had adversely affected the proximate composition of fish meat in A.nobilis. hence, more research work is required to verify these findings.

\section{Conclusion}

The results showed that BPA at sublethal concentration changes the hematological and biochemical parameters of fish, A.nobilis, and these parameters can be used to detect adverse effects of BPA in aquatic environments and to determine the physiological condition of fish. Histopathological studies are therefore conducted to confirm the degree of damage in vital organs of fish especially the liver. In contrast, the introduction of such compounds into rivers should be restricted, although carps (A.nobilis) are natural inhabitants of freshwater environments and are desired species in countries like Pakistan as 
food. The findings of this research work have indicated that environmental contaminants probably had adversely affected the proximate composition of fish meat in A.nobili. However, more research work is required to verify these findings

\section{Declarations}

Conflict of interest: All the authors carefully read the paper and declare that they have no financial/personal conflict of interests.

Ethical Approval: This study was approved by the bio ethical committee of Institute of Pure and Applied Biology, Zoology Division, Bhauddin Zakariya University, Multan, Pakistan

Consent to Participate: All the authors equally participated. and gave their consent to publish the study in this journal

Consent to Publish: All the authors gave their consent to publish the study in this journal

Authors Contributions: Riaz Hussain and Rehana Iqbal planed and designed the experiments. Rabia Akram and Riaz Hussain conducted the experiments. Rabia Akram, Riaz Hussain and Rehana lqbal involved data collection and interpretation. Rehana Iqbal and Muhammad Ali involved in manuscript preparation.

Funding: This research work was not funded any national and international funding agency and is part of $\mathrm{PhD}$ thesis.

Availability of data and materials: The datasets used and/or analysed during the current study are available from the first author on reasonable request (Rabia Akram).

\section{References}

1. Abdel-Latif H.M.R., Khashaba A.M.A., 2017. Subchronic toxicity of Nile tilapia with different exposure routes to Microcystisaeruginosa: histopathology, liver functions, and oxidative stress biomarkers. Vet World 10, 955-963. https://doi.org/10.14202/vetworld.2017. 955-963

2. Abdel-Tawwab M. and Hamed H.S., 2018. Effect of bisphenol A toxicity on growth performance, biochemical variables and oxidative stress biomarkers of Nile tilapia, Oreochromis niloticus (L.). $\mathrm{J}$ Appl Ichthyol . 1-9.

3. Adoamnei E, Mendiola J, Vela-Soria F, Fernández MF, Olea N, Jorgensen N, Swan SH, TorresCantero AM, (2018) Urinary bisphenol A concentrations are associated with reproductive parameters in young men. Environmental research 161, 122-128. https://doi.org/10.1016/j.envres.2017.11.002

4. Amaroli A, Gallus L, Ferrando S (2018) Permethrin drastically affects the developmental cycle of the non-target slime mould Dictyosteliumdiscoideum. Chemosphere 193: 1-7. 
5. Arslan H, Özdemir S, Altun S (2017) Cypermethrintoxication leads to histopathological lesions and induces inflammation and apoptosis in common carp (Cyprinuscarpio L.). Chemosphere 180: 491499.

6. Ayoola S.O., Ajani E.K., 2008. Histopathological Effects of cypermethrin on juvenile African catfish Clarias gariepinus. World Journal of Biological Research. 001, 1-14.

7. Bahey, N. G., Abd Elaziz, H. O. \& Elsayed Gadalla, K. K. (2019) Potential Toxic Effect of Bisphenol A on the Cardiac Muscle of Adult Rat and the Possible Protective Effect of Omega-3: A Histological and Immunohistochemical Study. Journal of microscopy and ultrastructure. 7(1), 1-8. https://doi.org/10.4103/JMAU.JMAU_53_18

8. Barakat R, Lin PCP, Rattan S, Brehm E, Canisso IF, Abosalum ME, Flaws JA, Hess R, Ko CM (2017) Prenatal exposure to DEHP induces premature reproductive senescence in male mice. Toxicol. Sci 156, 96-108. [CrossRef]

9. Baralic, K., Djordjevic, A. B., Živancevic, K., Antonijevic, E., Anđelkovic, M., Javorac, D., Curcic, M., Bulat, Z., Antonijevic, B. and Đukic-Cosic, D. (2020) Toxic Effects of the Mixture of Phthalates and Bisphenol A-Subacute Oral Toxicity Study in Wistar Rats. International Journal of Environmental Research and Public Health 17, 746.

10. Bavinck M (2018) Enhancing the Wellbeing of Tamil Fishing Communities (and Government Bureaucrats too): The role of ur panchayats along the Coromandel Coast, India. In Social Wellbeing and the Values of Small-scale Fisheries Springer Cham 175-194.

11. Benjamin K., Co E., Competente J., \& De Guzman H., 2019. Histopathological Effects of Bisphenol A on Soft Tissues of Corbicula fluminea Mull. Toxicology and Environmental Health Sciences. 11, 3644. 10.1007/s13530-019-0386-4.

12. Bose M. T. J., llavazhahan M, Tamilselvl R, Viswanathan M. 2013. Effect of Heavy Metals on the Histopathology of Gills and Brain of Fresh Water Fish Catla catla. Biomed Pharmacol J. 6(1).

13. Brown, A. R., Green, J. M., Moreman, J., Gunnarsson, L. M., Mourabit, S., Ball, J., Winter, M. J., Trznadel, M., Correia, A., Hacker, C., Perry, A., Wood, M. E., Hetheridge, M. J., Currie, R. A. \& Tyler, C. R. (2019) Cardiovascular Effects and Molecular Mechanisms of Bisphenol A and Its Metabolite MBP in Zebrafish. Environmental science \& technology. 53(1), 463-474. https://doi.org/10.1021/acs.est.8b04281

14. Carnevali O., Notarstefano V., Olivotto I., Graziano M., Gallo P., Di Marco P., llaria \& Vaccari L., Mandich, A., Giorgini E., Maradonna F., 2017. Dietary administration of EDC mixtures: A focus on fish lipid metabolism. Aquatic Toxicology. 185. 10.1016/j.aquatox.2017.02.007.

15. Cervantes-Camacho I., Guerrero-Estévez S.M., López M.F., Alarcón-Hernández E., López-López E., 2020. Effects of Bisphenol A on Foxl2 Gene Expression and DNA Damage in Adult Viviparous Fish Goodea atripinnis. J Toxicol Environ Health A. 83, 95-112.

16. Ching-Chang L, Ling-Ying J, Yi-Ling K, Chung-Yu C, Chia-Yi H, Chung-Feng H, Chien-Jung T (2015) Characteristics of nonylphenol and bisphenol $A$ accumulation by fish and implications for ecological and human health. Sci Total Environ 502, 417-425. 
17. Chomnawang, C., Nantachai, K., Yongsawatdigul, J., Thawornchinsombut, S. and Tungkawachara, S. (2007). Chemical and biochemical changes in hybrid catfish fillet stored at $4{ }^{\circ} \mathrm{C}$ and its gel properties. Food Chemistry. 103, 420-427. http://dx.doi.org/10.1016/j.foodchem.2006.07.039.

18. Das K.M and Mukherjee S.C, 2000. A histopathological study of carp (Labeo rohita) exposed to hexachlorocyclohexane. Veterrinarski arhiv. 70 (4), 169-180.

19. Ding S.Q, Zhu G.W, Wei Z., Wang Q., Wu C.L., Sember A., Pelikánová S., Cioffı M.D.B., Šlechtová V. , Hatanaka T., Doan H.D., Martin Knytl M., and Ráb P.J, 2005. Study on the growth and development of Grass Carp, Silver Carp, Bighead Carp and Black Carp. Agric Sci, 33, 1660-1662

20. Eggen RIL, Bengtsson BE, Bowmer CT, Gerritsen AAM, Gibert M, Hylland K, Johnson AC, Leonards PEG, Nakari T, Norrgren L, Sumpter JP, Suter MJF, Svenson A, Pickering AD (2003) Search for the evidence of endocrine disruption in the aquatic environment: lessons to be learned from joint biological and chemical monitoring in the European Project COMPREHEND. Pure Appl Chem 75: 2445-2450.

21. Eweda SM, Newairy AS, Abdou HM, \& Gaber, AS (2020) Bisphenol A-induced oxidative damage in the hepatic and cardiac tissues of rats: The modulatory role of sesame lignans. Experimental and Therapeutic Medicine 19: 33-44. https://doi.org/10.3892/etm.2019.8193

22. Faheem M., Khaliq S., Lone K.P., 2019. Effect of Bisphenol-A on Serum Biochemistry and Liver Function in the Freshwater Fish,Catla catla. Pak Vet J. 39(1), 71-75.

23. Faheem, M. and Lone, K.P. (2017) Oxidative stress and histopathologic biomarkers of exposure to bisphenol-A in the freshwater fish, Ctenopharyngodon idella. Braz J Pharm Sci 53, e17003.

24. Flint S, Markle T, Thompson S, Wallace E (2012) Bisphenol A exposure, effects, and policy: a wildlife perspective. J Environ Manage 104, 19-34. doi:10.1016/j.jenvman.2012.03.021

25. Fukuhori N., Kitano, $M$ and Kimura H., 2005. Toxic effects of bisphenol $A$ on sexual and asexual reproduction in Hydra oligactis. Archives of environmental contamination and toxicology. 48, 495500

26. Geetharathan T., \& Josthna P.,2016. Effect of BPA on protein, lipid profile and immuno-histo chemical changes in placenta and uterine tissues of albino rat. 8, 260-268.

27. Ghaffar A, Hussain R, Abbas A, Khan R, Akram K, Latif H, Ali S., Baig S., Du X., Ahrar Khan A. (2019) Assessment of genotoxic and pathologic potentials of fipronil insecticide in Labeo rohita (Hamilton, 1822). Toxin Reviews 1556-9551.

28. Ghaffar A, Hussain R, Abbas G, et al., 2017b. Arsenic and copper sulfate in combination causes testicular and serum biochemical changes in White Leghorn cockerels. Pak Vet J. 37, 375-80.

29. Ghaffar A., Hussain R., Abbas G., Ali M.H., Saleem M., Khan T., Malik R., Ahmad H., 2017 a. Cumulative effects of sodium arsenate and diammoniumphosphate on growth performance, hematobiochemistry and protoplasm in commercial layer. Pak Vet J .37 (3), 257-262

30. Ghaffar A., Hussain R., Abbas G., Kalim M., Khan A., Ferrando S., Gallus L., Ahmad Z., 2018. Fipronil (Phenylpyrazole) induces hemato-biochemical, histological, and genetic damage at low doses in common carp, Cyprinus carpio (Linnaeus, 1758). Ecotoxicology 27, 1261-1271. 
31. Ghaffar A., Hussain R., Aslam M., Abbas G., Khan A., 2016. Arsenic and Urea in Combination Alters the Hematology, Biochemistry and Protoplasm in Exposed Rahu Fish (Labeo rohita) (Hamilton, 1822). Turk. J. Fish. Aquat. Sci. 16, 289-296.

32. Ghaffar, A., Hussain, R., Noreen, S., Abbas, G., Chodhary, I.R., Khan, A., Ahmed, Z., Khan, M.K., Akram, K., Ulhaq, M., Ahmad, N., Ali, F. and Niaz, M. (2020) dose and time related pathological and genotoxic studies on thiamethaxam in freshwater fish (Labeo rohita) in Pakistan. Pak Vet $\mathrm{J}$

33. Ghazala G, Salma S, Al-Ghanim KA, Mahboob S, (2018) The Effect of Profenofos on the Nutritive Composition of Major Carp for Estimating Maximum Allowable Toxicant Concentration of the Pesticide. Pol J Environ Stud 28: 1127-1133.

34. Glassmeyer ST, Furlong ET, Kolpin DW, Batt AL, Benson R, Boone JS, Conerly O, Donohue M.J, King DN, Kostich MS, Mash HE, Pfaller SL, Schenck KM, Simmons JE, Varughese EA, Vesper SJ, Villegas EN., Wilson VS (2017) Nationwide reconnaissance of contaminants of emerging concern in source and treated drinking waters of the United States. The Science of the total environment 909922. https://doi.org/10.1016/j.scitotenv.2016.12.004

35. Gobi N., Vaseeharan B., Rekha R., Vijayakumar S., Faggio C., 2018. Bioaccumulation, cytotoxicity and oxidative stress of the acute exposure selenium in Oreochromis mossambicus . Ecotoxicology and Environmental Safety.162, 147- 159. https://doi.org/10.1016/j.ecoenv.2018.06.070

36. Gul S.T., Khan A., Farooq M., Niaz S., Ahmad M., Khatoon A., Hussain R., Saleemi M.K., Hassan M.F., 2017. Effect of sub lethal doses of thiamethoxam (a pesticide) on hemato-biochemical values in cockerels. Pak Vet J. 37(2), 135-138.

37. Hamed H. and Abdel-Tawwab M., 2017. Ameliorative Effect of Propolis Supplementation on Alleviating Bisphenol-A Toxicity: Growth Performance, Biochemical Variables, and Oxidative Stress Biomarkers of Nile tilapia, Oreochromis niloticus (L.). Comparative Biochemistry and Physiology Part C Comparative Pharmacology. 202. 10.1016/j.cbpc.2017.08.001.

38. Huang Q, Liu Y, Chen Y, Fang C, Chi Y, Zhu H, Lin Y, Ye G, Dong S (2018) New insights into the metabolism and toxicity of bisphenol A on marine fish under long-term exposure 242, 914-921.

39. Hultmann, L. and Rusted, T. (2004) Iced storage of Atlantic salmon (Salmo salar) effects on endogenous enzymes and their impact on muscle proteins and texture. Food Chemistry 87, 31-34. http://dx.doi.org/10.1016/j.foodchem.2003.10.013.

40. Hussain B, Sultana T, Sultana S, Ahmed Z, Mahboob S, (2018) Study on impact of habitat degradation on proximate composition and amino acid profile of Indian major carps from different habitats. Saudi Journal of Biological Sciences. 25: 755-759. DOI:10.1016/j.sjbs.2018.02.004.

41. Hussain R, Ghaffar A, Ali H.M., Abbas R.Z., Khan J.A, Khan I.A., Ahmad I \& Iqbal Z., 2017. Analysis of different toxic impacts of Fipronil on growth, hemato-biochemistry, protoplasm and reproduction in adult cockerels. Toxin Rev. DOI: 10.1080/15569543.2017

42. Hussain, R., Ali, F, Rafique, A., Ghaffar, A., Jabeen, G., Rafay, M., Liaqat S., Khan, I., Malik, R., Khan, M.K., Niaz, M., Akram, K. and Masood, A. (2019) Exposure to sub-acute concentrations of glyphosate 
induces clinico-hematological, serum biochemical and genotoxic damage in adult cockerels. Pak Vet J. 39, 181-186.

43. Ibrahim, S.A., Gaber, H.S., El-Ghamdi, F.A. and El-Kashif M.A., (2014) Histopathogical Alterations in Fish Organs as Potential and Direct Biomarkers of Pollution. The Egyptian society for environmental sciences. 9 (1), 25 -31.

44. Iheanacho, S.C., Nworu, S.A., Ogueji, E.O., Nnatuanya, I., Mbah, C.E., Anosike, F., Okoye, C., Ibrahim, U.B., Kogi, E. and Haruna, M., (2017) Comparative assessment of proximate content and organoleptic quality of African catfish (Clarias gariepinus) processed by smoking and solar drying methods. African Journal of Agricultural Research. 12, 2824-2829. http://dx.doi.org/10.5897/AJAR2017.12599

45. Islam S.M.M., Sultana R., Imran M.M., Fatima Tuj Jannat M., Ashaf-Ud-Doulah M.M., Rohani F., Brown C., Shahjahan M., 2019. Elevated temperature affects growth and hemato-biochemical parameters, inducing morphological abnormalities of erythrocytes in Nile tilapia Oreochromis niloticus. Aquaculture research. 51, 4361-4371.

46. Karami A, Goy YM, Jahromi MF, Lazorchak JM, Abdullah M, Couteny SC (2016) Diploid and triploid African catfish (Clarias gariepinus) differ in biomarker responses to the pesticide chlorpyrifos. Science of Total Environment 204: 557-558.

47. Karnam S. S., Ghosh R. C., Mondal S., Mondal M., 2015. Evaluation of subacute bisphenol - A toxicity on male reproductive system. Veterinary world. 8(6), 738-744.

https://doi.org/10.14202/vetworld.2015.738-744.

48. Karthikraj R., Vasu A. K., Balakrishna K., Sinha R. K. \& Kannan K. 2017. Occurrence and fate of parabens and their metabolites in five sewage treatment plants in India. Science of the Total Environment, 593-594, 592-598. https://doi.org/10.1016/j.scitotenv.2017.03.173

49. Karwacka A, Zamkowska D, Radwan M, Jurewicz J (2017) Exposure to modern, widespread environmental endocrine disrupting chemicals and their effect on the reproductive potential of women: An overview of current epidemiological evidence. Hum Fertil 22, 2-25. [Google Scholar] [CrossRef]

50. Kim J. J., Kumar S., Kumar V., Lee Y. M., Kim Y. S., Kumar V., 2019. Bisphenols as a Legacy Pollutant, and Their Effects on Organ Vulnerability. International journal of environmental research and public health, 17(1), 112. https://doi.org/10.3390/ijerph17010112

51. Krishnapriya K., Ganesan S., Subramaniam N., Mathan R., Vettaegounder M., 2017. Sublethal concentration of bisphenol A induces hematological and biochemical responses in an Indian major carp Labeo rohita. Ecohydrology \& Hydrobiology. 17, 10. 1016/j.ecohyd.2017.06.003.

52. Kumari K. and Khare A., 2018. Integration of Biomarker Approach in Pollution Monitoring Programme of Aquatic Ecosystem. In Biosynthetic Technology and Environmental Challenges. Springer, Singapore. 331-354.

53. Lakshmaiah G., 2017. Brain histopathology of the fish Cyprinus carpio exposed to lethal concentrations of an organophosphate insecticide phorate. International Journal of Advanced Research and Development. 668-672 
54. Leem YH, Oh S, Kang HJ, Kim JH, Yoon J, Chang JS. (2017) BPA-toxicity via superoxide anion overload and a deficit in $\beta$-catenin signaling in human bone mesenchymal stem cells, Environ. Toxicol 32: 344-352.

55. Mahboob, S., Al-Ghanim, K. A., Al-Balawi, H. F., Al-Misned, A.F. \& Ahmed, Z., (2019). Study on assessment of proximate composition and meat quality of fresh and stored Clarias gariepinus and Cyprinus carpio. Brazilian Journal of Biology. 79(4): 651-658. Epub October 25, 2018.https://doi.org/10.1590/1519-6984.187647

56. Makinwa T., Uadia P., 2017. Occurrence of Bisphenol A (BPA) in Ponds, Rivers and Lagoons in SouthWestern Nigeria and Uptake in Cat Fish Evidence of Environmental Contamination Food and Public Health. 7(1), 1-6.

57. Metzler M. and Erika P., 2001. Chemistry of natural and anthropogenic endocrine active compounds. In: The Handbook of Environmental Chemistry. 3. Endocrine Disruptors. Ed Springer -Verlag, Berlin Heidelberg.

58. Mita L, Bianco M., Viggiano E., Zollo F., Bencivenga U, Sica V, Monaco G, Portaccio M, Diano N, Colonna A, Lepore M, Canciglia P, Mita DG (2011) Bisphenol A content in fish caught in two different sites of the Tyrrhenian Sea (Italy). Chemosphere 82: 405-410.

59. Moselhy W.A., 2015. Bisphenol A Toxicity in Adult Male Rats: Hematological, Biochemical and Histopathological Approach.

60. Murali M., Athif P., Suganthi P., Bukhari, S.A., Syed Mohamed S. H. E., Basu H., Singhal R. K., 2018. Toxicological effect of Al2O3 nanoparticles on histoarchitecture of the freshwater fish Oreochromis mossambicus . Environmental Toxicology and Pharmacology. 59, 74- 81. https://doi.org/10.1016/j.etap.2018.03.004

61. Muralidharan L, (2014) Chronic toxicity studies on proximate composition of Cyprinus carpio exposed to fenthion. International Journal of Fisheries and Aquatic Studies 1: 26-221.

62. Murata M, Kang JH (2018) Bisphenol A (BPA) and cell signaling pathways. Biotechnol. Adv. 36: 311327. [Google Scholar] [CrossRef] [PubMed]

63. Nashwa A., Abu-Aita , 2014. Genotoxic, Hematological and Biochemical Changes Induced by Phenol Exposure in African Catfish (Clarias gariepinus). Global Veterinaria. 13, 316-324.

64. Oğuz A. R. and Oğuz E. K., 2020. Histopathology and immunohistochemistry of gills of Van fish (Alburnus tarichi Güldenstädt, 1814) infected with myxosporean parasites. Journal of histotechnology, 43(2), 76-82. https://doi.org/10.1080/01478885.2019.1686848

65. Osibona, A.O. and Ezekiel, M.O., (2014) Chemical, sensory and microbiological changes of spotted gruntter (Pomadasysommersonnii) under ice storage. African Journal of Food Agriculture Nutrition and Development. 14, 2141-2160.

66. Pal S., Reddy P.B., 2018. Bisphenol a (bpa) inducedhistopathological and biochemical alterations in the liver and kidney of stinging catfish heteropneustes fossilis. trends in fisheries research. 7, 23194758. 
67. Pal S., Sarkar K., Nath P. P., Mondal M., Khatun A \& Paul G., 2017. Bisphenol S impairs blood functions and induces cardiovascular risks in rats. Toxicology reports, 4, 560- 565.

68. Pal, S., Reddy P.B., 2018. Bisphenol a (bpa) inducedhistopathological and biochemical alterations in the liver and kidney of stinging catfish heteropneustes fossilis. trends in fisheries research. 7, 23194758.

69. Pathania R.R., Bankar P.B., Choudhary S.Y., Sharma A. A., Zade A.K., Zade S.B., Shende B.G. and Dofe D.T., 2019. Effect of bisphenol A on certain biochemical and hematological parameters in the african catfish, Clarias gariepinus. IJRSFP (USA). 10, 10: 35233-35235

70. Pedà, C., Caccamo, L., Fossi, M. C., Gai, F., Andaloro, F., Genovese, L., Perdichizzi, A., Romeo, T. \& Maricchiolo, G. (2016) Intestinal alterations in European sea bass Dicentrarchus labrax (Linnaeus, 1758) exposed to microplastics: Preliminary results. Environmental pollution (Barking, Essex : 1987). 212, 251-256. https://doi.org/10.1016/j.envpol.2016.01.083

71. Pradip, M. \& Davendra, M. \& Kumar, Y.K. \&Neha, G. \& Sandeep, K., (2019) Haematological and histological changes in fish Heteropneustes fossilis exposed to pesticides from industrial waste water. Human and Ecological Risk Assessment: An International Journal. 25: 1-28.

10.1080/10807039.2018.1482736.

72. Prins G, Ye SH, Birch L, Zhang X, Cheong A, Lin H, Calderon-Gierszal E, Groen J, Hu WY, Ho SM, Breemen RBV (2017) Prostate Cancer Risk and DNA Methylation Signatures in Aging Rats following Developmental BPA Exposure A Dose-Response Analysis. Environ. Heal. Perspect. 125: 077007. [Google Scholar] [CrossRef] [PubMed]

73. Pugazhvendan S.R., Narendiran J.N., Kumaran R.G., Kumaran S., Alagappan K.M., 2009. Effect of Malathion Toxicity in the Freshwater Fish Ophiocephalus punctatus-A Histological and Histochemical Study. World Journal of Fish and Marine Sciences. 1(3), 218-224.

74. Qin F, Wang L, Wang X, Liu S, Xu P, Wang H (2013) Bisphenol A affects gene expression of gonadotropin-releasing hormones and type I $\mathrm{GnRH}$ receptors in brains of adult rare minnow Gobiocypris rarus. Comp Biochem Physiol C 157: 192-202.

75. Rao PS, Babun B, Raju RR (2010) Study the effect of chlorpyrifos on proteins in fresh water fish Labeo rohita by using HPLC method. International Journal Research Pharmaceutical Biomedical Science 1: 5.

76. Rathee, Radha, 2015. Effect of detergent on histology of fish intestine. International Journal of Scientific Research and Reviews. 4(1), 07 - 15.

77. Ratn A., Prasad R., Awasthi Y., Kumar M., Misra A. and Trivedi S.P., 2018. Zn 2+ induced molecular responses associated with oxidative stress, DNA damage and histopathological lesions in liver and kidney of the fish, Channa punctatus (Bloch, 1793). Ecotoxicol. Environ. Safety. 151,10-20.

78. Rattan S, Zhou C, Chiang C, Mahalingam S, Brehm E., Flaws JA (2017) Exposure to endocrine disruptors during adulthood: Consequences for female fertility. J Endocrinol 233: R109-R129. [Google Scholar] [CrossRef] [PubMed] 
79. Reddy P.B., 2017. Productivity of Chambal River in Relation to Water Quality. World J. Pharmacy Pharmaceut. Sci. 6, 1466-1475.

80. Reddy P.B., 2017. Statistical approach for the assessment of water quality parameters of Chambal River at Nagda. Life Sciences Int. Res. J. 4, 38-41.

81. Renaud L., Silveira W., Hazard E. S., Simpson J., Falcinelli S., Chung D., Carnevali O., \& Hardiman G., 2017. The Plasticizer Bisphenol A Perturbs the Hepatic Epigenome: A Systems Level Analysis of the miRNome. Genes, 8(10), 269. https://doi.org/10.3390/genes8100269

82. Richardson SD, Ternes TA (2017) Water Analysis: Emerging Contaminants and Current Issues Anal Chem 90: 398-428. [Google Scholar] [CrossRef] [PubMed]

83. Routledge E.J., Parker J., Odum J., Ashby J., Sumpter J.P., 1998. Some alkyl hydroxy benzoate preservatives (parabens) are estrogenic. Toxicol Appl Pharmacol. 153(1), 12-19. [PubMed] [Google Scholar]

84. Sana KMP, Indulkar ST, Lateef AHS, Pai R (2017) Lethal and sublethal Toxicity of an organophosphate pesticide, phorate 10G on fingerlings of tilapia Sp. International Journal Pure Applied Bioscience 5: 1153.

85. Sayed A.E.H. and Hamed H.S., 2017. Induction of apoptosis and DNA damage by 4-nonylphenol in African catfish (Clarias gariepinus) and the antioxidant role of Cydonia oblonga. Ecotoxicol Environ. Saf. 139, 96-101.

86. Scarano WR, Bedrat A, Alonso-Costa LG, Aquino AM, Fantinatti EAB, Justulin AL, Barbisan LF, Freire PP, Flaws AJ, Lemos B, (2019) Exposure to an environmentally Relevant Phthalate Mixture During Prostate Development Induces microRNA Upregulation and Transcriptome Modulation in Rats. Toxicol. Sci. 171: 84-97.

87. Singh N.N., Srivastava A.K., 2010. Haematological parameters as bioindicators of insecticide exposure in teleosts. Ecotoxicology 19 (5), 838-854.

88. Sisodiya M., Khare M. and Kanhere R.R., 2018. Hepatotoxic effect of bisphenol A on H.Fossilis. Trends in fisheries research. 7, 2319-4758.

89. Sivashanmugam P, Mullainadhan V, Karundevi B (2017) Dose-dependent effect of bisphenol-A on insulin signaling molecules in cardiac muscle of adult male rat. Chem Biol Interact 266: 10-16.

90. Smarr M, Kannan K, Louis GB (2016) Endocrine disrupting chemicals and endometriosis. Fertil. Steril 106: 959-966. [Google Scholar] [CrossRef] [PubMed]

91. Sobha K, Poonima A, Harini P, Veeraiah KA (2007) study on biochemical changes in the freshwater fish, Catla catla (Hamilton) exposed to the heavy metal toxicant cadmium chloride. Kathmandu Univ J Sci Eng Technol 1(4):1-11.

92. Staples C., van der Hoeven N., Clark K., Mihaich E., Woelz J., Hentges S., 2018. Distributions of concentrations of bisphenol A in North American and European surface waters and sediments determined from 19 years of monitoring data. Chemosphere. 201, 448-458.

93. Staples C.A., Dome P.B., Klecka G.M., Oblock S.T., Harris L.R., 1998. A review of the environmental fate, effects, and exposures of bisphenol A. Chemosphere 36, 2149-2173. 
94. Sulekha BT, Mercy TVA (2011) Pesticide induced changes in the proximate composition of a freshwater fish for estimating maximum allowable toxicant concentration of the pesticide under tropical conditions. Indian Journal of Fisheries 58: 85.

95. Sun Q., Wang Y., Li Y., Ashfaq M., Dai L., Xie X., Yu C.P., 2017. Fate and mass balance of bisphenol analogues in wastewater treatment plants in Xiamen City, China. Environ. Pollut. 22, 542-549.

96. Sweilum, Mohamed (2006) Effect of sublethal toxicity of some pesticides on growth parameters, haematological properties and total production of Nile tilapia (Oreochromis niloticus L.) and water quality of ponds. Aquaculture Research 37: 1079 - 1089. 10.1111/j.1365-2109.2006.01531.x.

97. Vandenberg LN, Hunt PA, Gore AC (2019) Endocrine disruptors and the future of toxicology testing lessons from CLARITY-BPA. Nat Rev Endocrinol. 15: 366-374. doi:10.1038/s41574-019-0173-y

98. Vandenberg LN, Hunt PA, Myers JP, Saal VFS (2013). Human exposures to bisphenol A: mismatches between data and assumptions. Rev Environ Health. 28: 37-58.

99. Vasu G., Sujatha L.B., Manju Bashini J., 2019. Histological Changes in Tilapia Exposed to Bisphenol A (BPA) Compound. International Journal of Advanced Scientific Research and Management. 4 (4).

100. Verma G, Khan MF, Akhtar W, Alam MM, Akhter M, Shaquiquzzaman M (2017) Molecular interactions of bisphenols and analogs with glucocorticoid biosynthetic pathway enzymes: an in-silico approach. Toxicol Mech Methods 1-10.

101. Wanda E, Nyoni H, Mamba BB, Msagati TAM (2017) Occurrence of Emerging Micropollutants in Water Systems in Gauteng, Mpumalanga, and North West Provinces, South Africa. Int J Environ Res Public Heal. 14: 79.

102. Wang Z., Liu H., Liu S., 2016. Low-Dose Bisphenol A Exposure: A Seemingly Instigating Carcinogenic Effect on Breast Cancer. Advanced science (Weinheim, Baden-Wurttemberg, Germany). 4(2). 1600248. https://doi.org/10.1002/advs.201600248

103. Wei P., Zhao F., Zhang X., Liu W., Jiang G., Wang H., Ru S., 2018. Transgenerational thyroid endocrine disruption induced by bisphenol $\mathrm{S}$ affects the early development of zebrafish offspring. Environmental Pollution, 243, 800- 808.

104. Willhite CC, Daston GP (2019) Bisphenol exposure, hazard and regulation. Toxicology .425: 152243. [Google Scholar] [CrossRef] [PubMed]

105. Wong YM, Li R, Lee CKF, Wan HT, Wong CKC (2017) The measurement of bisphenol A and its analogues, perfluorinated compounds in twenty species of freshwater and marine fishes, a timetrend comparison and human health based assessment. Mar Pollut Bull 124 (2): 743-752.

106. Xu, J., Zhou, L., Wang, S., Zhu, J., Liu, T., Jia, Y., Sun, D., Chen, H., Wang Q., Xu F., Zhang Y., Liu H., Zhang T, \& Ye L. (2018) Di-(2-ethylhexyl)-phthalate induces glucose metabolic disorder in adolescent rats. Environmental science and pollution research international. 25, 3596-3607. https://doi.org/10.1007/s11356-017-0738-z

107. Yaghoobi Z., Safahieh A., Ronagh M., Movahedinia A., Mousavi S., 2017. Hematological changes in yellowfin seabream (Acanthopagrus latus) following chronic exposure to bisphenol A. Comparative Clinical Pathology. 10.1007/s00580-017-2530-3. 
108. Zhang P., Li T., Wu X., Nice E.C., Haung C., Zhang Y., 2020. Oxidative stress and diabetes: antioxidative strategies. Front. Med. Springer . https://doi.org/10.1007/s11684-019-0729-1.

109. Zhou L, Chen H, Xu Q, Han X, Zhao Y, Song X, Zhao ., Ye L (2019) The eff ect of di-2- ethylhexyl phthalate on inflammation and lipid metabolic disorder in rats. Ecotoxicol Environ. Saf. 170: 391398.

\section{Tables}


Table 1

Body weight and absolute weight of different visceral tissues of A.nobilis exposed to different concentrations of bisphenol A.

\begin{tabular}{|c|c|c|c|c|}
\hline \multirow[t]{2}{*}{ Parameters/day } & \multicolumn{4}{|c|}{ Groups/Treatments } \\
\hline & $A(0.0)$ & $B(500 \mu g / L)$ & $C(1000 \mu \mathrm{g} / \mathrm{L})$ & $D(1500 \mu g / L)$ \\
\hline \multicolumn{5}{|l|}{ Body weight (g) } \\
\hline 15 & $163.35 \pm 2.59$ & $161.62 \pm 2.20$ & $161.42 \pm 2.00$ & $162.95 \pm 1.01$ \\
\hline 30 & $174.60 \pm 2.63$ & $173.12 \pm 0.86$ & $172.67 \pm 1$ & $170.32 \pm 1.27$ \\
\hline 45 & $184.67 \pm 1.97$ & $182.25 \pm 1.67$ & $183.05 \pm 0.87$ & $177.42 \pm 1.85$ \\
\hline 60 & $202.62 \pm 2.36$ & $195.45 \pm 1.01$ & $192.97 \pm .70$ & $184.65 \pm 1.46^{*}$ \\
\hline \multicolumn{5}{|c|}{ Absolute weight of liver (g) } \\
\hline 15 & $2.30 \pm 0.02$ & $2.38 \pm 0.01$ & $2.38 \pm 0.01$ & $2.42 \pm 0.01$ \\
\hline 30 & $2.39 \pm 0.01$ & $2.46 \pm 0.00$ & $2.48 \pm 0.01$ & $2.53 \pm 0.01$ \\
\hline 45 & $2.43 \pm 0.00$ & $2.49 \pm 0.00$ & $2.55 \pm 0.01$ & $2.62 \pm 0.01$ \\
\hline 60 & $2.48 \pm 0.00$ & $2.51 \pm 0.00$ & $2.58 \pm 0.01$ & $2.95 \pm 0.03^{*}$ \\
\hline \multicolumn{5}{|c|}{ Absolute weight of gills } \\
\hline 15 & $3.96 \pm 0.02$ & $3.98 \pm 0.04$ & $4.03 \pm 0.02$ & $4.14 \pm 0.01$ \\
\hline 30 & $4.16 \pm 0.02$ & $4.20 \pm 0.00$ & $4.25 \pm 0.01$ & $4.32 \pm 0.00$ \\
\hline 45 & $4.26 \pm 0.01$ & $4.27 \pm 0.00$ & $4.33 \pm 0.02$ & $4.40 \pm 0.00$ \\
\hline 60 & $4.30 \pm 0.01$ & $4.38 \pm 0.01$ & $4.46 \pm 0.01$ & $5.53 \pm 0.02^{*}$ \\
\hline \multicolumn{5}{|c|}{ Absolute weight of Kidneys } \\
\hline 15 & $1.95 \pm 0.01$ & $2.01 \pm 0.03$ & $2.03 \pm .0 .02$ & $2.12 \pm 0.01$ \\
\hline 30 & $2.09 \pm 0.00$ & $2.16 \pm 0.00$ & $2.19 \pm 0.01$ & $2.26 \pm 0.01$ \\
\hline 45 & $2.15 \pm 0.00$ & $2.18 \pm 0.00$ & $2.24 \pm 0.01$ & $2.32 \pm 0.01$ \\
\hline 60 & $2.19 \pm 0.01$ & $2.24 \pm 0.00$ & $2.30 \pm 0.01$ & $2.90 \pm 0.02^{\star}$ \\
\hline \multicolumn{5}{|c|}{ Absolute weight of brain } \\
\hline 15 & $0.75 \pm 0.01$ & $0.78 \pm 0.01$ & $0.79 \pm 0.00$ & $0.81 \pm 0.03$ \\
\hline 30 & $0.84 \pm 0.02$ & $0.84 \pm 0.01$ & $0.83 \pm 0.01$ & $0.82 \pm 0.21$ \\
\hline 45 & $0.96 \pm 0.04$ & $0.95 \pm 0.01$ & $0.91 \pm 0.03$ & $0.90 \pm 0.01$ \\
\hline 60 & $0.98 \pm 0.04$ & $0.98 \pm 0.03$ & $1.01 \pm 0.00$ & $1.09 \pm 0.01$ \\
\hline
\end{tabular}


Table 2

Relative weight of different visceral tissues of A. nobilis exposed to different concentration of bisphenol A.

\begin{tabular}{|c|c|c|c|c|}
\hline \multirow[t]{2}{*}{ Parameters/days } & \multicolumn{4}{|c|}{ Groups/Treatments } \\
\hline & $A(0.0)$ & $B(500 \mu g / L)$ & $C(1000 \mu \mathrm{g} / \mathrm{L})$ & $D(1500 \mu \mathrm{g} / \mathrm{L})$ \\
\hline \multicolumn{5}{|c|}{ Relative weight of liver } \\
\hline 15 & $1.41 \pm 0.03$ & $1.47 \pm 0.02$ & $1.47 \pm 0.01$ & $1.49 \pm 0.01$ \\
\hline 30 & $1.38 \pm 0.01$ & $1.45 \pm 0.01$ & $1.44 \pm 0.01$ & $1.45 \pm 0.01$ \\
\hline 45 & $1.32 \pm 0.01$ & $1.36 \pm 0.01$ & $1.39 \pm 0.00$ & $1.48 \pm 0.01$ \\
\hline 60 & $1.22 \pm 0.01$ & $1.28 \pm 0.00$ & $1.33 \pm 0.00$ & $1.751 \pm 0.02 *$ \\
\hline \multicolumn{5}{|c|}{ Relative weight of gills } \\
\hline 15 & $2.43 \pm 0.02$ & $2.46 \pm 0.03$ & $2.49 \pm 0.02$ & $2.54 \pm 0.02$ \\
\hline 30 & $2.39 \pm 0.02$ & $2.47 \pm 0.02$ & $2.46 \pm 0.02$ & $2.48 \pm 0.01$ \\
\hline 45 & $2.30 \pm 0.01$ & $2.34 \pm 0.01$ & $2.36 \pm 0.00$ & $2.48 \pm 0.02$ \\
\hline 60 & $2.12 \pm 0.02$ & $2.24 \pm 0.01$ & $2.31 \pm 0.00$ & $2.70 \pm 0.02^{*}$ \\
\hline \multicolumn{5}{|c|}{ Relative weight of Kidneys } \\
\hline 15 & $1.19 \pm 0.01$ & $1.24 \pm 0.02$ & $1.26 \pm 0.02$ & $1.30 \pm 0.01$ \\
\hline 30 & $1.20 \pm 0.02$ & $1.27 \pm 0.00$ & $1.27 \pm 0.01$ & $1.29 \pm 0.01$ \\
\hline 45 & $1.16 \pm 0.01$ & $1.20 \pm 0.01$ & $1.22 \pm 0.00$ & $1.30 \pm 0.01$ \\
\hline 60 & $1.08 \pm 0.00$ & $1.14 \pm 0.00$ & $1.19 \pm 0.00$ & $1.37 \pm 0.01^{*}$ \\
\hline \multicolumn{5}{|c|}{ Relative weight of brain (\%) } \\
\hline 15 & $0.45 \pm 0.01$ & $0.48 \pm 0.00$ & $0.49 \pm 0.00$ & $0.49 \pm 0.00$ \\
\hline 30 & $0.48 \pm 0.00$ & $0.49 \pm 0.00$ & $0.50 \pm 0.00$ & $0.51 \pm 0.00$ \\
\hline 45 & $0.49 \pm 0.00$ & $0.52 \pm 0.00$ & $0.52 \pm 0.00$ & $0.53 \pm 0.01$ \\
\hline 60 & $0.46 \pm 0.00$ & $0.50 \pm 0.00$ & $0.52 \pm 0.00$ & $0.57 \pm 0.01$ \\
\hline
\end{tabular}


Table 3

Various hematological parameters of fish exposed to different concentrations of bisphenol A.

\begin{tabular}{|c|c|c|c|c|}
\hline \multirow[t]{2}{*}{ Parameters/days } & \multicolumn{4}{|c|}{ Groups/Treatments } \\
\hline & $A(0.0)$ & B $(500 \mu g / L)$ & $C(1000 \mu \mathrm{g} / \mathrm{L})$ & $D(1500 \mu \mathrm{g} / \mathrm{L})$ \\
\hline \multicolumn{5}{|c|}{ Red blood cell count } \\
\hline 15 & $3.77 \pm 0.11$ & $3.71 \pm 0.15$ & $3.69 \pm 0.07$ & $3.66 \pm 0.10$ \\
\hline 30 & $3.74 \pm 0.13$ & $3.67 \pm 0.08$ & $3.60 \pm 0.09$ & $3.34 \pm 0.06$ \\
\hline 45 & $3.74 \pm 0.09$ & $3.63 \pm 0.12$ & $3.26 \pm 0.15^{\star}$ & $3.04 \pm 0.11^{*}$ \\
\hline 60 & $3.73 \pm 0.15$ & $3.51 \pm 0.13$ & $3.13 \pm 0.12^{\star}$ & $2.86 \pm 0.07 *$ \\
\hline \multicolumn{5}{|c|}{ Hemoglobin concentration $(\mathrm{g} / \mathrm{dl})$} \\
\hline 15 & $9.13 \pm 0.25$ & $9.13 \pm 0.15$ & $9.08 \pm 0.12$ & $9.03 \pm 0.17$ \\
\hline 30 & $9.23 \pm 0.3$ & $9.14 \pm 0.13$ & $8.99 \pm 0.14$ & $8.58 \pm 0.12$ \\
\hline 45 & $9.25 \pm 0.19$ & $9.05 \pm 0.32$ & $8.71 \pm 0.23$ & $7.90 \pm 0.16^{*}$ \\
\hline 60 & $9.21 \pm 0.31$ & $8.95 \pm 0.11$ & $7.54 \pm 0.16^{*}$ & $7.12 \pm 0.11^{*}$ \\
\hline \multicolumn{5}{|l|}{ White blood counts } \\
\hline 15 & $19.6 \pm 0.27$ & $20.5 \pm 0.46$ & $20.7 \pm 0.47$ & $21.4 \pm 0.36$ \\
\hline 30 & $19.6 \pm 0.41$ & $21.2 \pm 0.38$ & $21.7 \pm 0.71$ & $23.0 \pm 0.42^{*}$ \\
\hline 45 & $19.7 \pm 0.28$ & $21.7 \pm 0.54$ & $23.7 \pm 0.53^{\star}$ & $25.0 \pm 0.32^{*}$ \\
\hline 60 & $19.8 \pm 0.24$ & $21.8 \pm 0.35$ & $24.1 \pm 0.67^{\star}$ & $25.4 \pm 0.79 *$ \\
\hline \multicolumn{5}{|l|}{ Pack cell volume } \\
\hline 15 & $33.5 \pm 0.52$ & $32.9 \pm 0.53$ & $32.5 \pm 0.88$ & $31.5 \pm 0.74$ \\
\hline 30 & $33.5 \pm 0.43$ & $32.6 \pm 0.61$ & $31.0 \pm 0.98$ & $30.1 \pm 0.52$ \\
\hline 45 & $33.7 \pm 0.34$ & $32.1 \pm 0.77$ & $28.4 \pm 0.73^{\star}$ & $28.1 \pm 0.74^{\star}$ \\
\hline 60 & $33.6 \pm 0.77$ & $31.1 \pm 0.88$ & $27.3 \pm 1.15^{\star}$ & $27.0 \pm 1.21^{*}$ \\
\hline \multicolumn{5}{|l|}{ Lymphocytes (\%) } \\
\hline 15 & $21.9 \pm 0.17$ & $21.4 \pm 0.25$ & $19.7 \pm 0.20$ & $19.6 \pm 0.11$ \\
\hline 30 & $22.1 \pm 0.17$ & $20.6 \pm 0.20$ & $19.3 \pm 0.30$ & $19.0 \pm 0.17$ \\
\hline 45 & $22.0 \pm 0.24$ & $20.6 \pm 0.13$ & $19.1 \pm 0.24$ & $17.7 \pm 0.17 *$ \\
\hline 60 & $22.1 \pm 0.18$ & $19.8 \pm 0.12$ & $18.4 \pm 0.43^{\star}$ & $17.1 \pm 0.19 *$ \\
\hline
\end{tabular}




\begin{tabular}{|lllll|}
\hline Parameters/days & \multicolumn{4}{l}{ Groups/Treatments } \\
\cline { 2 - 5 } & $\mathbf{A}(\mathbf{0 . 0})$ & $\mathbf{B}(500 \mu \mathrm{g} / \mathrm{L})$ & $\mathbf{C}(1000 \mu \mathrm{g} / \mathrm{L})$ & $\mathbf{D}(\mathbf{1 5 0 0} \boldsymbol{\mu g} / \mathrm{L})$ \\
\hline Monocytes (\%) & & & & \\
\hline 15 & $4.15 \pm 0.12$ & $4.10 \pm 0.10$ & $4.06 \pm 0.15$ & $4.06 \pm 0.17$ \\
\hline 30 & $4.16 \pm 0.09$ & $4.10 \pm 0.09$ & $3.97 \pm 0.11$ & $3.95 \pm 0.21$ \\
\hline 45 & $4.16 \pm 0.17$ & $4.04 \pm 0.12$ & $3.91 \pm 0.22^{\star}$ & $3.74 \pm 0.25^{\star}$ \\
\hline 60 & $4.23 \pm 0.07$ & $3.83 \pm 0.15$ & $3.47 \pm 0.23^{\star}$ & $3.38 \pm 0.14^{\star}$ \\
\hline Neutrophils (\%) & & & & \\
\hline 15 & $21.4 \pm 0.78$ & $22.7 \pm 0.28$ & $23.6 \pm 0.26$ & $23.6 \pm 0.17$ \\
\hline 30 & $21.8 \pm 0.40$ & $22.9 \pm 0.23$ & $24.0 \pm 0.29$ & $26.9 \pm 0.22^{\star}$ \\
\hline 45 & $21.8 \pm 0.56$ & $23.5 \pm 0.27$ & $24.8 \pm 0.25$ & $27.1 \pm 0.24^{*}$ \\
\hline 60 & $22.2 \pm 0.49$ & $23.4 \pm 0.60$ & $26.4 \pm 0.38^{\star}$ & $29.2 \pm 0.25^{\star}$ \\
\hline
\end{tabular}


Table 4

Various serum biochemical parameters of fish exposed to different concentrations of bisphenol A.

\begin{tabular}{|c|c|c|c|c|}
\hline \multirow[t]{2}{*}{ Parameters/days } & \multicolumn{4}{|c|}{ Groups/Treatments } \\
\hline & $A(0.0)$ & $B(500 \mu g / L)$ & $C(1000 \mu \mathrm{g} / \mathrm{L})$ & $D(1500 \mu \mathrm{g} / \mathrm{L})$ \\
\hline \multicolumn{5}{|c|}{ Albumin quantity (mg/dL) } \\
\hline 15 & $2.83 \pm 0.07$ & $2.78 \pm 0.11$ & $2.76 \pm 0.05$ & $2.72 \pm 0.08$ \\
\hline 30 & $2.87 \pm 0.09$ & $2.76 \pm 0.09$ & $2.72 \pm 0.07$ & $2.70 \pm 0.06$ \\
\hline 45 & $2.87 \pm 0.05$ & $2.74 \pm 0.07$ & $2.68 \pm 0.09$ & $2.25 \pm 0.07^{*}$ \\
\hline 60 & $2.86 \pm 0.08$ & $2.70 \pm 0.07$ & $2.32 \pm 0.08^{\star}$ & $2.22 \pm 0.04^{*}$ \\
\hline \multicolumn{5}{|c|}{ Total proteins (mg/dL) } \\
\hline 15 & $3.83 \pm 0.02$ & $3.80 \pm 0.02$ & $3.75 \pm 0.00$ & $3.68 \pm 0.00$ \\
\hline 30 & $3.89 \pm 0.01$ & $3.75 \pm 0.01$ & $3.61 \pm 0.01$ & $3.49 \pm 0.02$ \\
\hline 45 & $3.89 \pm 0.02$ & $3.74 \pm 0.01$ & $3.17 \pm 0.02^{\star}$ & $3.01 \pm 0.04^{\star}$ \\
\hline 60 & $3.90 \pm 0.00$ & $3.65 \pm 0.03$ & $3.12 \pm 0.10^{\star}$ & $2.84 \pm 0.08^{\star}$ \\
\hline \multicolumn{5}{|c|}{ Aspartate aminotransferase (U/L) } \\
\hline 15 & $14.2 \pm 0.35$ & $15.0 \pm 0.23$ & $15.6 \pm 0.14$ & $15.9 \pm 0.19$ \\
\hline 30 & $14.1 \pm 0.17$ & $15.6 \pm 0.17$ & $16.3 \pm 0.16$ & $16.5 \pm 0.18$ \\
\hline 45 & $14.0 \pm 0.19$ & $15.9 \pm 0.16$ & $16.7 \pm 0.21$ & $18.2 \pm 0.25^{\star}$ \\
\hline 60 & $14.3 \pm 0.24$ & $16.3 \pm 0.19$ & $18.9 \pm 0.35^{\star}$ & $19.5 \pm 0.28^{*}$ \\
\hline \multicolumn{5}{|c|}{ Alkaline phosphatase (U/L) } \\
\hline 15 & $25.8 \pm 0.27$ & $26.0 \pm 0.22$ & $26.1 \pm 0.21$ & $26.7 \pm 0.20$ \\
\hline 30 & $25.1 \pm 0.25$ & $26.4 \pm 0.23$ & $26.6 \pm 0.26$ & $27.3 \pm 0.28$ \\
\hline 45 & $25.1 \pm 0.25$ & $26.9 \pm 0.23$ & $28.9 \pm 0.19$ & $29.3 \pm 0.23^{*}$ \\
\hline 60 & $25.2 \pm 0.31$ & $27.4 \pm 0.19$ & $29.8 \pm 0.52^{\star}$ & $31.7 \pm 0.65^{\star}$ \\
\hline \multicolumn{5}{|c|}{ Alanine aminotransferase (U/L) } \\
\hline 15 & $22.6 \pm 0.23$ & $22.8 \pm 0.18$ & $23.3 \pm 0.19$ & $23.7 \pm 0.14$ \\
\hline 30 & $22.8 \pm 0.19$ & $23.1 \pm 0.18$ & $23.8 \pm 0.18$ & $24.3 \pm 0.16$ \\
\hline 45 & $22.9 \pm 0.23$ & $23.4 \pm 0.21$ & $24.0 \pm 0.17$ & $26.0 \pm 0.15^{\star}$ \\
\hline 60 & $22.6 \pm 0.36$ & $24.2 \pm 0.19$ & $27.4 \pm 0.20^{\star}$ & $28.7 \pm 0.22^{\star}$ \\
\hline
\end{tabular}




\begin{tabular}{|c|c|c|c|c|}
\hline \multirow[t]{2}{*}{ Parameters/days } & \multicolumn{4}{|c|}{ Groups/Treatments } \\
\hline & $A(0.0)$ & $B(500 \mu g / L)$ & $C(1000 \mu \mathrm{g} / \mathrm{L})$ & $D(1500 \mu \mathrm{g} / \mathrm{L})$ \\
\hline \multicolumn{5}{|c|}{ Lactate dehydrogenase (U/L) } \\
\hline 15 & $242.9 \pm 2.40$ & $247.0 \pm 1.72$ & $251.7 \pm 1.64$ & $252.6 \pm 1.23$ \\
\hline 30 & $246.3 \pm 1.08$ & $249.7 \pm 1.31$ & $254.0 \pm 1.22$ & $255.4 \pm 0.71$ \\
\hline 45 & $248.5 \pm 1.80$ & $253.5 \pm 0.89$ & $256.5 \pm 1.21$ & $268.5 \pm 2.23^{\star}$ \\
\hline 60 & $247.8 \pm 0.86$ & $256.4 \pm 0.42$ & $273.9 \pm 2.40 *$ & $280.0 \pm 0.85^{\star}$ \\
\hline \multicolumn{5}{|l|}{ Urea (mg/dL) } \\
\hline 15 & $8.43 \pm 0.10$ & $8.68 \pm .17$ & $8.75 \pm 0.03$ & $9.14 \pm 0.01$ \\
\hline 30 & $8.55 \pm 0.07$ & $8.84 \pm 0.16$ & $9.31 \pm 0.17$ & $9.43 \pm 0.04$ \\
\hline 45 & $8.59 \pm 0.09$ & $8.93 \pm 0.17$ & $9.51 \pm 0.12$ & $10.74 \pm 0.10$ * \\
\hline 60 & $8.64 \pm 0.10$ & $9.15 \pm 0.01$ & $10.97 \pm 0.01 *$ & $11.2 \pm 0.31^{*}$ \\
\hline \multicolumn{5}{|l|}{ Creatinine (mg/dL) } \\
\hline 15 & $1.11 \pm 0.00$ & $1.14 \pm 0.00$ & $1.16 \pm 0.00$ & $1.18 \pm 0.00$ \\
\hline 30 & $1.13 \pm 0.00$ & $1.15 \pm 0.00$ & $1.19 \pm 0.00$ & $1.22 \pm 0.00$ \\
\hline 45 & $1.15 \pm 0.00$ & $1.17 \pm 0.00$ & $1.22 \pm 0.01$ & $1.31 \pm 0.02^{\star}$ \\
\hline 60 & $1.16 \pm 0.00$ & $1.20 \pm 0.008$ & $1.35 \pm 0.04^{\star}$ & $1.53 \pm 0.02^{\star}$ \\
\hline \multicolumn{5}{|l|}{ Cholesterol (mg/dL) } \\
\hline 15 & $151.4 \pm 0.72$ & $154.3 \pm 0.74$ & $155.0 \pm 0.83$ & $157.8 \pm 0.59$ \\
\hline 30 & $150.6 \pm 0.77$ & $155.8 \pm 0.19$ & $157.6 \pm 0.50$ & $160.5 \pm 1.36$ \\
\hline 45 & $152.1 \pm 1.14$ & $156.2 \pm 0.46$ & $158.6 \pm 0.44$ & $164.4 \pm 1.64^{\star}$ \\
\hline 60 & $152.4 \pm 1.06$ & $157.5 \pm 0.34$ & $165.9 \pm 0.47 *$ & $170.3 \pm 1.99 *$ \\
\hline \multicolumn{5}{|l|}{ Glucose (mg/dL) } \\
\hline 15 & $28.0 \pm 0.57$ & $29.4 \pm 0.57$ & $30.4 \pm 0.57$ & $32.1 \pm 0.57$ \\
\hline 30 & $29.1 \pm 0.58$ & $30.4 \pm 0.38$ & $31.6 \pm 0.21$ & $32.4 \pm 0.43$ \\
\hline 45 & $29.1 \pm 0.51$ & $31.1 \pm 0.51$ & $32.7 \pm 0.51$ & $33.9 \pm 0.51^{*}$ \\
\hline 60 & $29.8 \pm 0.36$ & $31.7 \pm 0.47$ & $34.7 \pm 1.22^{\star}$ & $37.8 \pm 0.74^{\star}$ \\
\hline \multicolumn{5}{|c|}{ Triglycerides (mg/dL) } \\
\hline 15 & $172.9 \pm 0.83$ & $173.1 \pm 1.14$ & $175.9 \pm 0.62$ & $177.2 \pm 0.85$ \\
\hline
\end{tabular}




\begin{tabular}{|lllll|}
\hline Parameters/days & \multicolumn{4}{l}{ Groups/Treatments } \\
\cline { 2 - 5 } & $\mathbf{A}(\mathbf{0 . 0})$ & $\mathbf{B}(\mathbf{5 0 0} \boldsymbol{\mu g} / \mathrm{L})$ & $\mathbf{C}(\mathbf{1 0 0 0} \boldsymbol{\mu g} / \mathrm{L})$ & $\mathrm{D}(\mathbf{1 5 0 0} \boldsymbol{\mu g} / \mathrm{L})$ \\
\hline 30 & $172.8 \pm 3.64$ & $174.5 \pm 2.45$ & $177.1 \pm 2.73$ & $180.1 \pm 1.06$ \\
\hline 45 & $173.7 \pm 2.65$ & $175.9 \pm 2.25$ & $188.3 \pm 3.70$ & $193.8 \pm 1.62^{\star}$ \\
\hline 60 & $174.1 \pm 0.32$ & $177.1 \pm 0.31$ & $189.2 \pm 1.76^{\star}$ & $198.9 \pm 1.90^{\star}$ \\
\hline
\end{tabular}


Table 5

Severity of different histopathological changes in various tissues of bighead carp exposed to various concentrations of bisphenol A.

\begin{tabular}{|c|c|c|c|}
\hline \multirow[t]{2}{*}{ Histopathological lesions } & \multicolumn{3}{|l|}{ Groups } \\
\hline & $B(500 \mu g / L)$ & $C(1000 \mu \mathrm{g} / \mathrm{L})$ & $D(1500 \mathrm{~g} / \mathrm{L})$ \\
\hline \multicolumn{4}{|l|}{ Liver } \\
\hline Congestion & + & ++ & ++++ \\
\hline Ceroid formation & + & ++ & ++++ \\
\hline Vauolar degeneration & ++ & ++++ & ++++ \\
\hline Hemorhages & + & ++ & ++++ \\
\hline Pyknosis & ++ & ++ & ++++ \\
\hline Nuclear hypertrophy & ++ & +++ & ++++ \\
\hline Karyorrhexis & ++ & ++++ & ++++ \\
\hline Karyolysis & ++ & ++ & ++++ \\
\hline Degeneration of hepatocyte & ++ & +++ & ++++ \\
\hline Hepatocytes with eccentric nuclei & ++ & ++++ & ++++ \\
\hline \multicolumn{4}{|l|}{ Kidneys } \\
\hline Congestion & + & +++ & ++++ \\
\hline Increased Bowman's space & ++ & +++ & ++++ \\
\hline Ceroid formation & + & ++ & +++ \\
\hline Edema & + & + & ++ \\
\hline Necrosis of tubular cells & ++ & +++ & ++++ \\
\hline Melanomacrophage aggregates & + & ++ & +++ \\
\hline Nuclear hypertrophy & + & ++ & ++++ \\
\hline Deterioration of glomerulus & ++ & +++ & ++++ \\
\hline Dneration and obiliteration of renal tubule & + & ++ & +++ \\
\hline Thyroidization & + & ++ & +++ \\
\hline \multicolumn{4}{|l|}{ Brain } \\
\hline Necrosis of neurons & + & ++ & +++ \\
\hline Cytoplasmic vacuolization & ++ & +++ & ++++ \\
\hline
\end{tabular}




\begin{tabular}{|c|c|c|c|}
\hline \multirow[t]{2}{*}{ Histopathological lesions } & \multicolumn{3}{|l|}{ Groups } \\
\hline & $B(500 \mu g / L)$ & C(1000 jg/L) & $\mathrm{D}(1500 \mathrm{~g} / \mathrm{L})$ \\
\hline Intracellular oedema & ++ & ++ & +++ \\
\hline Congestion of neural cells & + & ++ & +++ \\
\hline \multicolumn{4}{|l|}{ Gills } \\
\hline Congestion & + & +++ & ++++ \\
\hline Congested cartilaginous core & + & ++ & ++++ \\
\hline Lamellar fusion & ++ & ++++ & ++++ \\
\hline Necrosis of lamellar pillar cells & + & +++ & ++++ \\
\hline Degeneration of cartilaginous core & ++ & ++++ & ++++ \\
\hline Lamellar atrophy & ++ & ++++ & ++++ \\
\hline Telangiectasia & + & ++ & +++ \\
\hline Uplifting of lamellae & ++ & ++++ & ++++ \\
\hline Disruption of primary lamellae & ++ & ++++ & ++++ \\
\hline Curling of secondary lamellae & ++ & +++ & ++++ \\
\hline Lamellar disorganization & ++ & +++ & ++++ \\
\hline
\end{tabular}


Table 6

Some change in meat composition of A.nobilis exposed to different concentrations of Bisphenol A.

\begin{tabular}{|c|c|c|c|c|}
\hline \multirow[t]{2}{*}{ Parameters/days } & \multicolumn{4}{|c|}{ Groups/Treatments } \\
\hline & $A(0.0)$ & B $(500 \mu g / L)$ & $C(1000 \mu \mathrm{g} / \mathrm{L})$ & $D(1500 \mu \mathrm{g} / \mathrm{L})$ \\
\hline \multicolumn{5}{|l|}{ Crude protein (\%) } \\
\hline 15 & $16.55 \pm 0.75$ & $16.40 \pm 0.49$ & $15.60 \pm 0.54$ & $15.00 \pm 0.30$ \\
\hline 30 & $16.67 \pm 0.38$ & $16.07 \pm 0.16$ & $15.15 \pm 0.45$ & $14.35 \pm 0.25$ \\
\hline 45 & $16.62 \pm 0.26$ & $15.37 \pm 0.11$ & $14.82 \pm 0.26$ & $13.12 \pm 0.17 *$ \\
\hline 60 & $16.25 \pm 0.29$ & $15.15 \pm 0.15$ & $12.52 \pm 0.24^{\star}$ & $12.71 \pm 0.11 *$ \\
\hline \multicolumn{5}{|l|}{ Lipids (\%) } \\
\hline 15 & $5.28 \pm 0.12$ & $5.18 \pm 0.01$ & $5.14 \pm 0.01$ & $5.13 \pm 0.00$ \\
\hline 30 & $5.24 \pm 0.01$ & $5.14 \pm 0.01$ & $5.02 \pm 0.02$ & $4.96 \pm 0.00$ \\
\hline 45 & $5.29 \pm 0.01$ & $5.05 \pm 0.01$ & $4.81 \pm 0.01^{\star}$ & $4.79 \pm 0.02^{\star}$ \\
\hline 60 & $5.32 \pm 0.02$ & $4.74 \pm 0.24$ & $4.50 \pm 0.07^{\star}$ & $4.36 \pm 0.05^{\star}$ \\
\hline \multicolumn{5}{|l|}{ Moisture (\%) } \\
\hline 15 & $78.02 \pm 0.45$ & $76.85 \pm 0.32$ & $75.92 \pm 0.49$ & $75.20 \pm 0.55$ \\
\hline 30 & $77.65 \pm 0.49$ & $74.95 \pm 0.60$ & $73.07 \pm 0.66$ & $72.07 \pm 0.50$ \\
\hline 45 & $77.22 \pm 0.46$ & $74.20 \pm 0.65$ & $71.05 \pm 0.96$ & $63.60 \pm 0.29 *$ \\
\hline 60 & $77.60 \pm 0.34$ & $73.27 \pm 0.41$ & $70.57 \pm 1.30$ & $62.20 \pm 1.02^{\star}$ \\
\hline \multicolumn{5}{|l|}{ Ash (\%) } \\
\hline 15 & $4.17 \pm 0.07$ & $4.21 \pm 0.02$ & $4.31 \pm 0.00$ & $4.38 \pm 0.02$ \\
\hline 30 & $4.16 \pm 0.01$ & $4.33 \pm 0.01$ & $4.43 \pm 0.02$ & $4.67 \pm 0.04$ \\
\hline 45 & $4.35 \pm 0.02$ & $4.35 \pm 0.02$ & $4.57 \pm 0.07$ & $4.91 \pm 0.04^{\star}$ \\
\hline 60 & $4.22 \pm 0.01$ & $4.42 \pm 0.03$ & $4.64 \pm 0.07$ & $5.23 \pm 0.07^{\star}$ \\
\hline
\end{tabular}

\section{Figures}



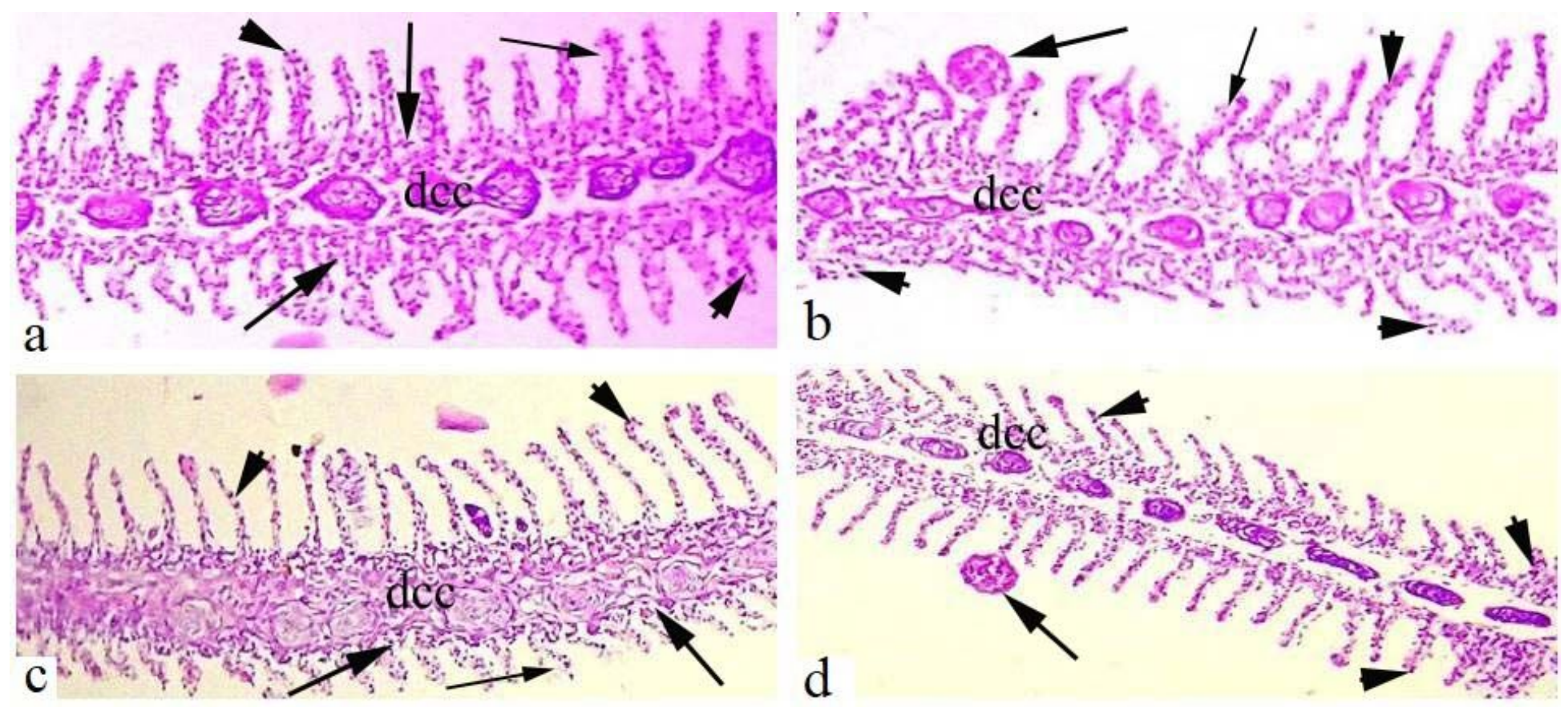

\section{Figure 1}

Photomicrograph of gills of bighead carp exposed to BPA (@1000 $\mu \mathrm{g} / \mathrm{L}$ ) and $1500 \mu \mathrm{g} / \mathrm{L}$ showing different microscopic lesions. A) gills showing necrosis of primary lamellar epithelial cells (arrow heads), secondary lamellar disorganization (thick arrows), disorganization of cartilaginous core (dcc) and sloughing of lamellar epithelium (thin arrow). B) sloughing of lamellar epithelium (thin arrow), disorganization of cartilaginous core (dcc), necrosis of primary lamellar epithelial cells (arrow heads) and aneurysm (thick arrow). C) necrosis of primary lamellar epithelial cells (arrow heads), disorganization of cartilaginous core (dcc), secondary lamellar disorganization (thick arrows) and necrosis of epithelium (thin arrow). D) aneurysm (thick arrow), lamellar epithelial cells (arrow heads) and disorganization of cartilaginous core (dcc). 

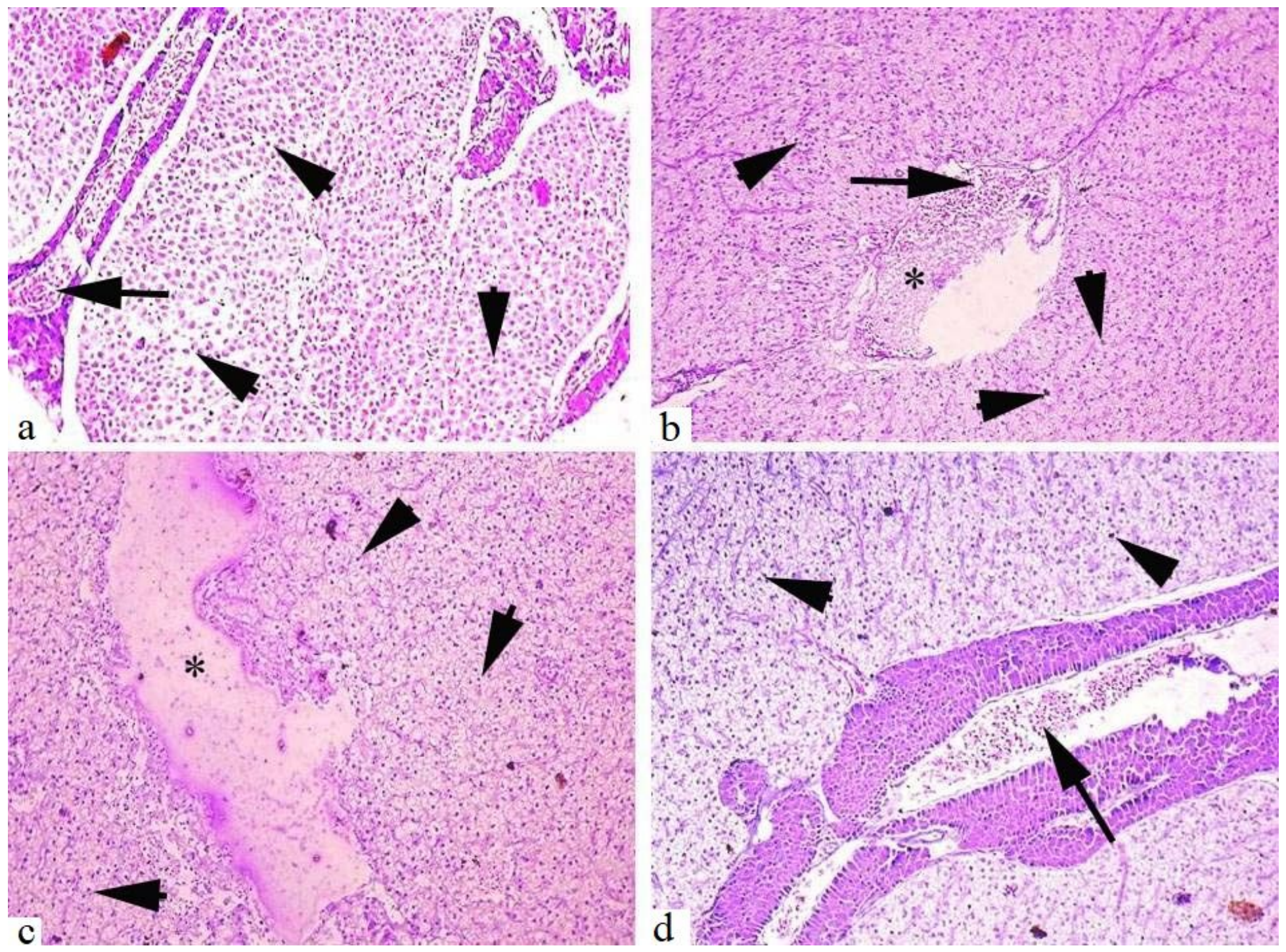

Figure 2

Photomicrograph of liver of bighead carp exposed to BPA (@1000 $\mu \mathrm{g} / \mathrm{L}$ ) and $1500 \mu \mathrm{g} / \mathrm{L}$ showing various microscopic changes a) congestion (arrow) and necrosis of hepatocyte (arrow heads). b) edema $(*)$, heamorrhages (arrow) and necrotic hepatocytes (arrow heads). c) edema (*) and necrosis of hepatocyte (arrow heads). d) heamorrhages (arrow) and necrosis of hepatocyte (arrow heads) at day 45 and 60 of trial. 

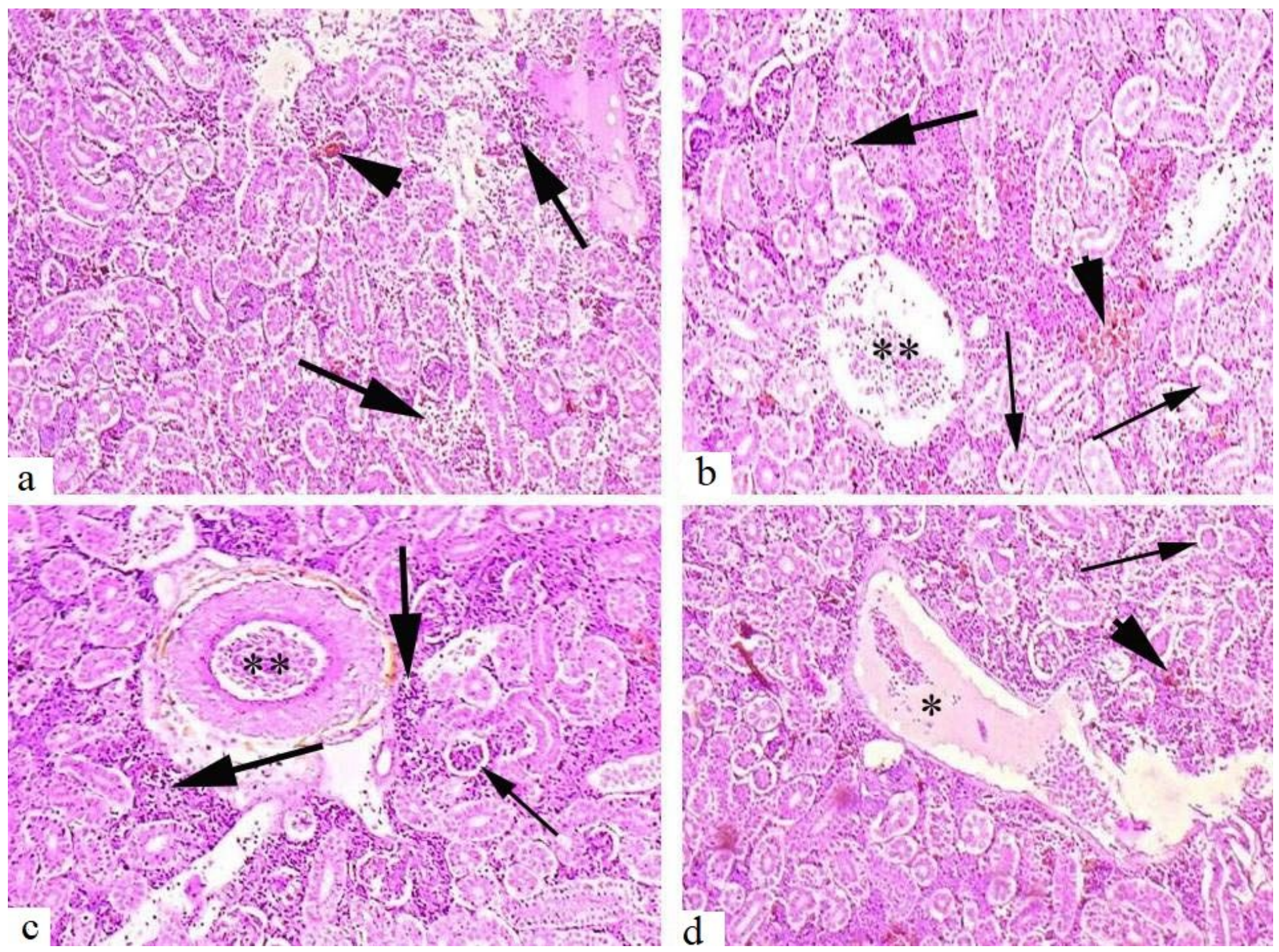

\section{Figure 3}

Photomicrograph of kidneys of bighead carp exposed to BPA (@1000 $\mu \mathrm{g} / \mathrm{L}$ ) and $1500 \mu \mathrm{g} / \mathrm{L}$ showing various microscopic changes a) ceroid formation and inflammatory cell accumulation (arrows). b) severe hemorrhage $\left({ }^{\star *}\right)$, ceroid formation (arrow head), expansion of Bowman's space (thin arrows) and inflammatory cell (thick arrow) at day 45 and 60 of experiment. 

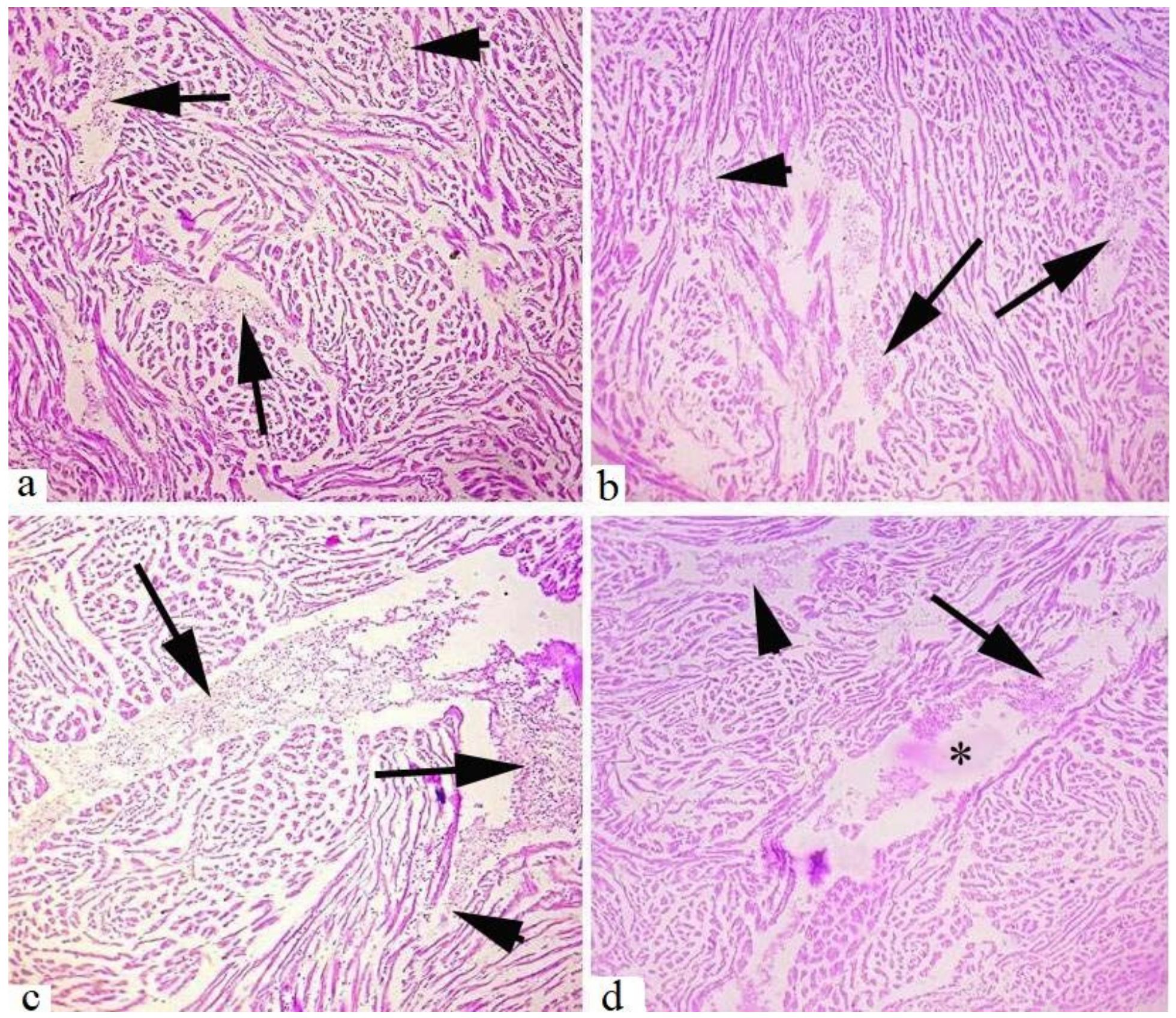

Figure 4

Photomicrograph of heart of bighead carp exposed to BPA (@1000 $\mu \mathrm{g} / \mathrm{L}$ ) and $1500 \mu \mathrm{g} / \mathrm{L}$ showing a) inflammatory exudate (arrows) and disorganization of cardiac mucles (arrow head). b) inflammatory exudate (arrows) and disorganization (arrow head). d) hemorrhage (arrow), edema (*) and disorganization of cardiac mucles (arrow head) at day 45 and 60 of experiment. 

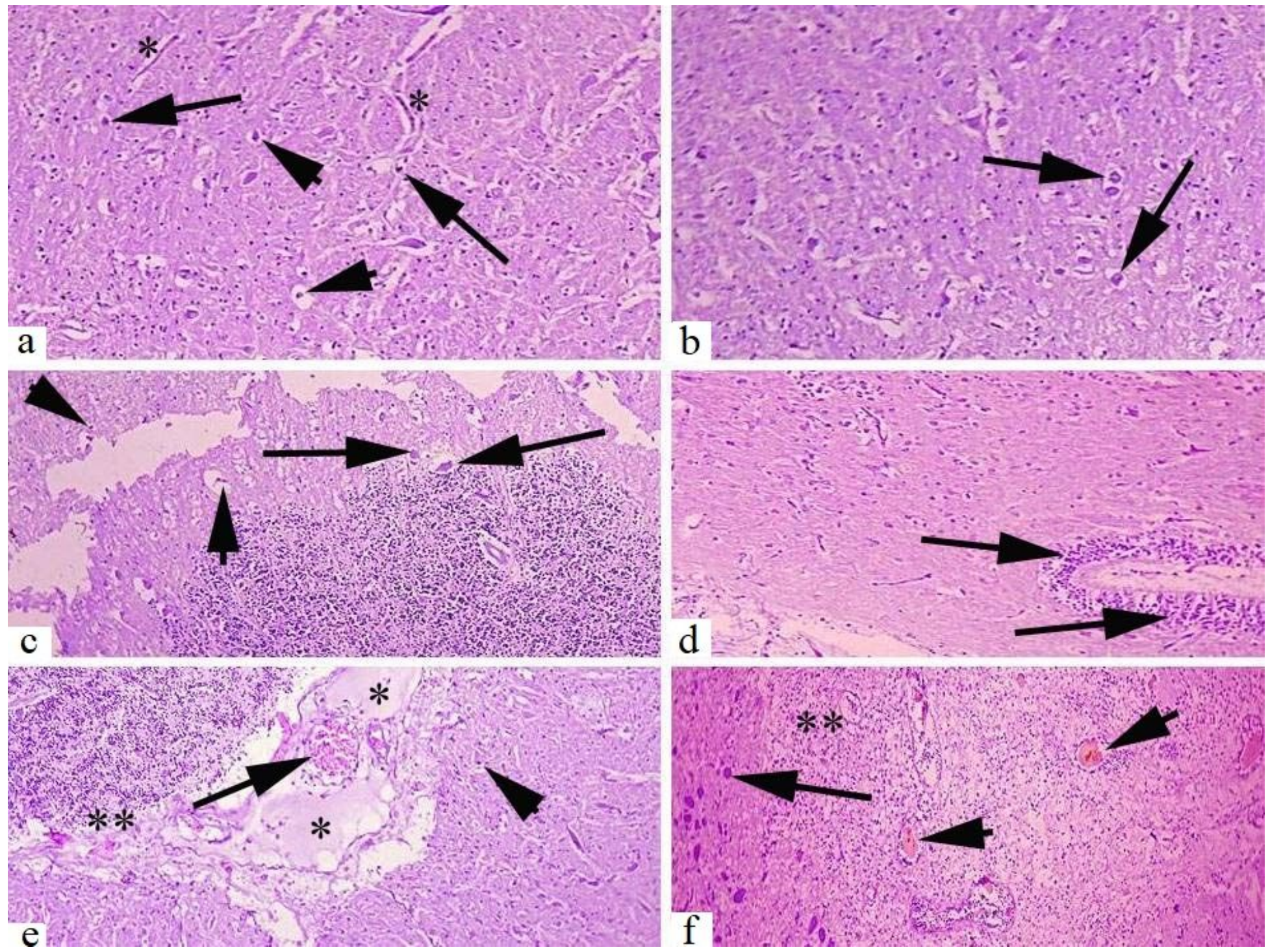

\section{Figure 5}

Photomicrograph of brain of bighead carp exposed to BPA (@1000 $\mu \mathrm{g} / \mathrm{L}$ ) and $1500 \mu \mathrm{g} / \mathrm{L}$ showing a) hyperemic vessels (*), necrosis of neurons (arrows) and degeneration of neurons (arrow heads). b) severe necrosis of neurons (arrows). c) necrosis of neurons (arrows) and degeration of neurons (arrow heads). d) inflammatory cells (arrows). e) severe edema $\left({ }^{\star}\right)$, severe hemorrhage (arrow), inflammatory cell acomulation ( ${ }^{* *}$ ) and necrosis of neuron (arrow head). j) ceroid formation (arrow heads), inflammatory cell acomulation (**) and necrosis of neurons (arrow) at day 45 and 60 of experiment. 